\title{
Differential Modulation of Excitatory and Inhibitory Striatal Synaptic Transmission by Histamine
}

\author{
Tommas J. Ellender, ${ }^{1}$ Icnelia Huerta-Ocampo, ${ }^{1}$ Karl Deisseroth, ${ }^{2}$ Marco Capogna, ${ }^{1}$ and J. Paul Bolam ${ }^{1}$ \\ ${ }^{1}$ MRC Anatomical Neuropharmacology Unit, Department of Pharmacology, University of Oxford, OX1 3TH, Oxford, United Kingdom, and ${ }^{2}$ Department of \\ Psychiatry and Behavioral Sciences, Stanford University, Stanford, California 94305
}

Information processing in the striatum is critical for basal ganglia function and strongly influenced by neuromodulators (e.g., dopamine). The striatum also receives modulatory afferents from the histaminergic neurons in the hypothalamus which exhibit a distinct diurnal rhythm with high activity during wakefulness, and little or no activity during sleep. In view of the fact that the striatum also expresses a high density of histamine receptors, we hypothesized that released histamine will affect striatal function. We studied the role of histamine on striatal microcircuit function by performing whole-cell patch-clamp recordings of neurochemically identified striatal neurons combined with electrical and optogenetic stimulation of striatal afferents in mouse brain slices. Bath applied histamine had many effects on striatal microcircuits. Histamine, acting at $\mathrm{H}_{2}$ receptors, depolarized both the direct and indirect pathway medium spiny projection neurons (MSNs). Excitatory, glutamatergic input to both classes of MSNs from both the cortex and thalamus was negatively modulated by histamine acting at presynaptic $\mathrm{H}_{3}$ receptors. The dynamics of thalamostriatal, but not corticostriatal, synapses were modulated by histamine leading to a facilitation of thalamic input. Furthermore, local inhibitory input to both classes of MSNs was negatively modulated by histamine. Subsequent dual whole-cell patch-clamp recordings of connected pairs of striatal neurons revealed that only lateral inhibition between MSNs is negatively modulated, whereas feedforward inhibition from fast-spiking GABAergic interneurons onto MSNs is unaffected by histamine. These findings suggest that the diurnal rhythm of histamine release entrains striatal function which, during wakefulness, is dominated by feedforward inhibition and a suppression of excitatory drive.

\section{Introduction}

The basal ganglia and particularly the input layer of the basal ganglia, the striatum, play a critical role in the control of motor behavior and cognitive function (Graybiel et al., 1994; Grillner et al., 2005; Yin and Knowlton, 2006). The main computational unit of the striatum is the GABAergic medium spiny projection neuron (MSN) of which there are at least two classes; the dopamine receptor 1 (D1)-expressing and dopamine receptor 2 (D2)expressing MSNs which correspond to the direct and indirect pathway neurons respectively (Gerfen et al., 1990; Smith et al., 1998). Both classes of MSN receive and integrate cortical and thalamic excitatory input (Kincaid et al., 1998; Lacey et al., 2007; Doig et al., 2010) and selectively innervate downstream basal ganglia nuclei and differently affect motor behavior (Kravitz et al., 2010). Their activity is controlled by local GABAergic and cholinergic interneurons (Kawaguchi et al., 1995; Mallet et al.,

Received June 21, 2011; revised Aug. 19, 2011; accepted Sept. 5, 2011.

Author contributions: T.J.E., M.C., and J.P.B. designed research; T.J.E. and I.H.-0. performed research; K.D. contributed unpublished reagents/analytic tools; T.J.E. analyzed data; T.J.E., M.C., and J.P.B. wrote the paper.

This research was supported by the European Community (FP7: HEALTH-F2-2008-201716) and the Medical Research Council, UK (Grant U138164490). We thank K. Newton, K. Whitworth, C. Francis, G. Hazel, L. Norman, and B. Micklem for technical assistance. We thank L. Upton and W. Nissen for help setting up mouse surgery, D. Kaetzel and M. Kohl for advice on optogenetic stimulation, S. Threlfell for comments on a draft of this manuscript, and K.C. Nakamura for advice on immunolabeling for preproenkephalin. An abstract of this work has been awarded the Young Investigators Award by the European Histamine Research Society.

Correspondence should be addressed to Tommas J. Ellender, MRC Anatomical Neuropharmacology Unit, Mansfield Road, 0X13TH, 0xford, UK. E-mail: tommas.ellender@pharm.ox.ac.uk.

DOI:10.1523/JNEUROSCI.3144-11.2011

Copyright $\odot 2011$ the authors $\quad 0270-6474 / 11 / 3115340-12 \$ 15.00 / 0$
2005), reciprocal inhibitory connections between neighboring MSNs (Tepper and Plenz, 2006) and neuromodulators such as dopamine (Schultz, 2002; Ungless, 2004; Surmeier et al., 2007), serotonin (Steinbusch, 1981; Mathur et al., 2011; Parent et al., 2011) and noradrenaline (Aston-Jones and Bloom, 1981).

The striatum also receives input from histaminergic neurons located in the tuberomamillary nucleus of the hypothalamus (Haas and Panula, 2003). Histaminergic neurons exhibit a diurnal rhythm in their activity, being active during wakefulness, especially during periods of increased attention (Takahashi et al., 2006), and relatively inactive or silent during sleep (Reiner and McGeer, 1987; Steininger et al., 1999; Takahashi et al., 2006). Recent studies using knock-out animals have suggested they play a role in mediating specific aspects of wakefulness (Parmentier et al., 2002; Anaclet et al., 2009). The striatum also displays a high density of histamine receptors (Hill and Young, 1980; MartinezMir et al., 1990; Vizuete et al., 1997; Pillot et al., 2002) suggesting that released histamine has the potential to exert widespread effects on striatal function. Indeed, it has been shown that histamine can modulate corticostriatal transmission in both rats and mice (Doreulee et al., 2001) and the intrinsic properties of striatal neurons (Munakata and Akaike, 1994).

The aim of this investigation was thus to define the role of histamine in controlling the activity of the striatal network. To achieve this aim we performed whole-cell patch-clamp recordings of identified D1- or D2-expressing MSNs in mouse brain slices and determined the effect of histamine on the membrane potential, excitatory afferents from the cortex and thalamus and 
local GABAergic input to MSNs. We further characterized the effects on GABAergic inputs by using dual whole-cell patchclamp recordings, investigating the effects of histamine on the unitary connections between fast-spiking GABAergic interneuronMSN and MSN-MSN pairs. We find that histamine suppresses the excitatory drive to MSNs, selectively alters the short-term dynamics of thalamostriatal synapses and abolishes feedback inhibition onto MSNs.

\section{Materials and Methods}

Animals. All experiments were performed on transgenic mouse lines of either sex which were bred and housed in accordance with the Animals (Scientific Procedures) Act (1986) and the Society of Neuroscience policy on the use of animals in neuroscience research. The majority of the recordings were performed on BAC transgenic mice that report subtypes of the dopamine receptor, either D1 or D2, by the presence of GFP (Mutant Mouse Regional Resource Centers, MMRRC). Details of the mice and the methods of BAC mice production have been published (Gong et al., 2003) and can be found on the GENSAT website [GENSAT (2009) The Gene Expression Nervous System Atlas (GENSAT) Project. In: NINDS, Contracts N01NS02331 and HHSN271200723701C, The Rockefeller University (New York), http://www.gensat.org/index.html]. Lhx6-GFP mice report a subset of GABAergic interneurons and were obtained from the MMRRC and kept as a heterozygous breeding line on a Swiss Webster background. CaMKII-cre mice express cre recombinase in all CaMKII-expressing neurons and were obtained from the Jackson Laboratory and kept as a homozygous breeding line.

Slice preparation. Oblique coronal striatal slices $(300-400 \mu \mathrm{m})$ were prepared from postnatal day 18-35 D1-GFP, D2-GFP, or Lhx6-GFP mice or, for optogenetic experiments, 1- to 4-month-old injected CaMKII-cre mice. Slices were taken between $\sim+1.60 \mathrm{~mm}$ and -1.30 $\mathrm{mm}$ from bregma. Mice were anesthetized with isoflurane and decapitated. Slices were prepared in artificial CSF (ACSF) containing the following (in mM): $130 \mathrm{NaCl}, 3.5 \mathrm{KCl}, 1.25 \mathrm{NaH}_{2} \mathrm{PO}_{4}, 5 \mathrm{MgCl}_{2}, 2.5 \mathrm{CaCl}_{2}$, $24 \mathrm{NaHCO}_{3}$, and 10 glucose, $\mathrm{pH}$ 7.2-7.4, bubbled with carbogen gas $\left(95 \% \mathrm{O}_{2} / 5 \% \mathrm{CO}_{2}\right)$. Slices were immediately transferred to a storage chamber containing ACSF (in mM): $130 \mathrm{NaCl}, 3.5 \mathrm{KCl}, 1.25 \mathrm{NaH}_{2} \mathrm{PO}_{4}$, $1.5 \mathrm{Mg} \mathrm{Cl}_{2}, 2.5 \mathrm{CaCl}_{2}, 24 \mathrm{NaHCO}_{3}$, and 10 glucose, $\mathrm{pH}$ 7.2-7.4, bubbled with carbogen gas, at $37^{\circ} \mathrm{C}$ for $30 \mathrm{~min}$ and subsequently maintained at room temperature until used for recording.

Recording. Whole-cell current-clamp and voltage-clamp recordings from single or pairs of dorsal striatal neurons were performed using glass pipettes, pulled from standard wall borosilicate glass capillaries containing the following: for whole-cell current-clamp (in $\mathrm{mM}$ ), 110 potassium gluconate, 40 HEPES, 2 ATP-Mg, $0.3 \mathrm{Na}-\mathrm{GTP}, 4 \mathrm{NaCl}$, and $4 \mathrm{mg} / \mathrm{ml}$ biocytin, $\mathrm{pH}$ 7.2-7.3 (osmolarity, 290-300 $\mathrm{mOsm} / \mathrm{L}$ ); and for whole-cell voltage-clamp (in $\mathrm{mm}$ ), 120 cesium gluconate, 40 HEPES, $4 \mathrm{NaCl}, 2$ ATP-Mg, 0.3 Na-GTP, 0.2 QX-314, and $4 \mathrm{mg} / \mathrm{ml}$ biocytin, pH 7.2-7.3 (osmolarity, 290-300 mOsm/L). Paired recordings of fast-spiking GABAergic interneuron (FSI)-MSN and MSN-MSN connected pairs were made using a high chloride concentration intracellular solution containing the following (in $\mathrm{mm}$ ): 105 potassium gluconate, $30 \mathrm{KCl}, 10$ HEPES, 4 ATP-Mg, $0.3 \mathrm{Na}-\mathrm{GTP}$, and $4 \mathrm{mg} / \mathrm{ml}$ biocytin (pH 7.2-7.3; osmolarity, 290-300 mOsm/L). All recordings were made using HEKA amplifiers with integrated A/D converter and acquired using Pulse or Patchmaster software (HEKA Electronik).

Stimulation and recording protocols. MSN afferents were stimulated electrically or optically. Electrical stimulation was performed by placing a glass stimulating electrode in the external capsule for activation of corticostriatal afferents, or for activation of inhibitory fibers at 100-200 $\mu \mathrm{m}$ from the patched MSN soma. Stimulation strength was set to evoke $\sim 1 / 3$ of maximum response corresponding to a stimulation strength of $100-$ $300 \mu \mathrm{A}$. Optical stimulation of corticostriatal and thalamostriatal afferents was performed using the optoLED system (Cairn Research), consisting of a $470 \mathrm{~nm}, 3.5 \mathrm{~W}$ LED mounted on a Zeiss Axioskop 2 FS microscope, to give $3 \mathrm{~ms}$ duration light pulses of $\sim 5 \%$ of maximum output power. The spot size corresponded to the area of the slice visualized using a $40 \times / 0.8$ numerical aperture water-immersion objective. Ac- tivation of excitatory afferents was performed in the presence of blockers of inhibitory GABAergic transmission including the $\mathrm{GABA}_{\mathrm{A}}$ receptor antagonist SR95331 $(10 \mu \mathrm{M})$ and $\mathrm{GABA}_{\mathrm{B}}$ receptor antagonist CGP52432 $(2 \mu \mathrm{M})$. Activation of inhibitory afferents was performed in the presence of blockers of excitatory transmission including the NMDA receptor antagonist D-AP5 $(50 \mu \mathrm{M})$ and AMPA/kainate receptor antagonist NBQX $(20 \mu \mathrm{M})$. Fibers were activated every $10 \mathrm{~s}$ and EPSCs or IPSCs were recorded in the patched MSN. Evoked EPSCs and IPSCs were recorded in whole-cell voltage-clamp mode at a holding potential respectively near $-80 \mathrm{mV}$ and $0 \mathrm{mV}$ (estimated reversal potential for glutamatergic transmission). For paired pulse stimulation, two stimulating pulses were consecutively given at $50 \mathrm{~ms}$ interval and repeated every $10 \mathrm{~s}$ for up to 20 times. Trains of pulses consisted of 9 pulses at $20 \mathrm{~Hz}$ followed by a recovery pulse $500 \mathrm{~ms}$ later, and was repeated every $30 \mathrm{~s}$ for up to 5 times. Baseline responses were measured for $5 \mathrm{~min}$ after which histamine, alone or in combination with histamine receptor antagonists, was washed in for $10 \mathrm{~min}$, followed by a $10 \mathrm{~min}$ washout. Dose-response experiments were performed using $10 \mathrm{~min}$ exposures to increasing concentrations of histamine $(1,5$ and $10 \mu \mathrm{M})$. Recording of MSN resting membrane potential was performed in whole-cell current-clamp mode. If the resting membrane potential of the patched neuron exhibited a stable baseline for $5 \min (<5 \%$ change) histamine, alone or in combination with histamine receptor antagonists, was washed in for $10 \mathrm{~min}$, followed by a $10 \mathrm{~min}$ washout while the membrane voltage was constantly monitored. Paired recordings were performed by evoking a single action potential in the presynaptic neuron using a suprathreshold current injection and recording the unitary IPSC (UIPSC) as an inward current from the postsynaptic neuron held near $-80 \mathrm{mV}$.

Viral transfection. Adeno-associated virus serotype 2 (AAV2) carrying fusion genes for channelrhodopsin $2(\mathrm{ChR} 2)$ and yellow fluorescent protein (YFP) were injected into the thalamus or cortex of CaMKII-cre mice between postnatal days 14 and 21. For thalamostriatal experiments, the intralaminar nuclei of the thalamus were targeted. For corticostriatal experiments, layers II/III of the cortex were targeted. Typical coordinates from bregma for thalamic injections were lateral, $0.7 \mathrm{~mm}$; posterior, 1.6 $\mathrm{mm}$; and $3.1 \mathrm{~mm}$ ventral to the surface of brain. For cortical injections the coordinates were lateral, $0.7 \mathrm{~mm}$; posterior, $0.1 \mathrm{~mm}$; and $0.3 \mathrm{~mm}$ ventral to the surface of brain. Viral DNA included the double-floxed sequence for ChR2(H134R)-EYFP driven by the elongation factor 1 promotor. AAV2 particles were produced at the University of North Carolina Gene Therapy Center Virus Vector Core. Typical titers were $\sim 10^{12}$ $\mathrm{IU} / \mathrm{ml}$. Injection volumes were 300-400 nl. After allowing 3-14 weeks for ChR2-YFP expression, acute striatal slices were prepared as described above.

Analysis of intracellular recordings. Data were analyzed offline using custom written procedures in Igor Pro (Wavemetrics). PSCs were detected as upward or downward deflections of $>2$ SDs above baseline. Paired pulse ratios were calculated by dividing the average slope of the second PSC with the average slope of the first PSC. Slopes of individual PSCs were determined between $20-80 \%$ of maximum PSC amplitude. Trains were analyzed by taking the amplitude of each PSC and dividing this by the amplitude of the first PSC. To extract correct amplitudes of postsynaptic responses lying on the decay phase of previous responses, the synaptic decay was fitted by an exponential curve and subtracted. For the MSN-MSN paired recordings the amplitudes of every three evoked uIPSCs were averaged due to the small amplitude responses and failures at these synapses. The input resistance was calculated from the slope of a line fitted to the injected current versus the steady-state membrane voltage when a family of hyperpolarizing and depolarizing current injections were applied (range, $-300 /+600 \mathrm{pA}$ ). The analysis of EPSC kinetics (peak amplitude, duration, rise time $(20-80 \%)$, half maximum peak, half decay time and time to peak) was performed on individual synaptic responses. Failure rate was calculated for individual pairs as the number of failures divided by the total number of stimulations and averaged over pairs.

Histological analyses. Following intracellular recording, the slices were fixed overnight in $4 \%$ paraformaldehyde and $15 \%$ saturated picric acid in $0.1 \mathrm{M}$ phosphate buffer ( $\mathrm{PB} ; \mathrm{pH} 7.4)$ at $4^{\circ} \mathrm{C}$. Slices were embedded in $5 \%$ agar and resectioned at $50 \mu \mathrm{m}$ on a vibrating microtome (VT1000S; Leica 
Microsystems). Autofluorescence was reduced by incubating the sections in $1 \%$ sodium borohydride in PBS for $10 \mathrm{~min}$ at room temperature. All sections were preincubated with 10-20\% normal donkey serum (NDS; Vector Laboratories) in PBS for $>1 \mathrm{~h}$ at room temperature. Biocytin-filled cells were visualized by incubating sections in 1:1000 streptavidin-Cy3 conjugate (ZyMax; Invitrogen) or 1:10,000 streptavidin-405 conjugate (Invitrogen) in PBS containing $0.3 \%$ Triton-X (PBS-Tx) overnight at $4^{\circ} \mathrm{C}$. GFP expression was confirmed for MSNs recorded from slices of D1- and D2-GFP mice and FSIs from Lhx6-GFP mice by incubating sections in 1:400 rabbit anti-GFP-Alexa Fluor 488 conjugate (Invitrogen) in PBS-Tx or in 1:1000 chicken anti-GFP (Aves Labs) in PBS-Tx and 1\% NDS overnight at $4^{\circ} \mathrm{C}$ followed by 1:500 donkey-anti-chicken-Alexa Fluor 488 fluorophore (Jackson ImmunoResearch Laboratories) in PBS-Tx for $2 \mathrm{~h}$ at room temperature. To define the subtype of MSN in recordings performed in CaMKII-cre mice, the sections were heated at $80^{\circ} \mathrm{C}$ in 10 mM sodium citrate, $\mathrm{pH} 6.0$, for $\sim 30$ min before incubation with 1:1000 rabbit anti-preproenkephalin (LifeSpan Biotechnology) in PBS-Tx and $1 \%$ NDS overnight at $4^{\circ} \mathrm{C}$ after which the reaction was revealed by incubating with donkey-anti-rabbit-Cy3 fluorophore (Jackson ImmunoResearch Laboratories) in PBS-Tx for $2 \mathrm{~h}$ at room temperature. The neurons that were immunopositive were classified as D2 or indirect pathway MSNs.

Histamine fibers were visualized in perfusion-fixed tissue of D1- or D2-GFP transgenic mice. The mice were transcardially perfused with 50 $\mathrm{ml}$ of ice-cold $0.1 \mathrm{M} \mathrm{PB}, \mathrm{pH}$ 7.4, followed by ice-cold 4\% 1-ethyl-3-[3dimethylaminopropyl] carbodiimide $\mathrm{HCl}$ (Thermo Fisher Scientific) in $0.1 \mathrm{M} \mathrm{PB}, \mathrm{pH}$ 7.4. The brains were removed and immersed in the same fixative for $3 \mathrm{~d}$ followed by $3 \%$ paraformaldehyde in $0.1 \mathrm{M} \mathrm{PB}$ for $1 \mathrm{~d}$. Sagittal vibratome sections $(40 \mu \mathrm{m})$ were collected and treated with a solution of $0.5 \%$ sodium borohydride for $30 \mathrm{~min}$. After rinsing, the sections were incubated with $10 \%$ normal goat serum in PBS-Tx for $2 \mathrm{~h}$ and double-immunolabeled to reveal GFP and histamine. Sections were incubated in 1:50,000 rabbit-anti-histamine (Immunostar) together with 1:1000 chicken-anti-GFP (Aves Labs) for at least $72 \mathrm{~h}$ at $4^{\circ} \mathrm{C}$. After this, sections were washed and incubated overnight at $4^{\circ} \mathrm{C}$ in a mixture of 1:500 biotinylated goat-anti-rabbit IgG (Vector Laboratories) and 1:100 goat-anti-chicken-Alexa Fluor 488 fluorophore (Invitrogen) secondary antibodies. The sections were then washed and incubated in ABC Elite (Vector Laboratories) for $4 \mathrm{~h}$ at room temperature after which the signal was amplified using 1:100,000 biotinylated tyramide in $50 \mathrm{~mm}$ PBS, pH 7.4 (see for detailed procedure (Kuramoto et al., 2009). Sections were washed thoroughly and then incubated overnight at $4^{\circ} \mathrm{C}$ in $1: 1500$ antistreptavidin-Cy3 fluorophore (ZyMax, Invitrogen).

To confirm the AAV injection were correctly targeted to the thalamic intralaminar nuclei $50 \mu \mathrm{m}$ sections were made from paraformaldehydefixed brains ( $4 \%$ in $0.1 \mathrm{M} \mathrm{PB}$ ) of injected CaMKII-cre mice used for experiments. Sections were incubated in $20 \%$ NDS (Vector Laboratories) for $45 \mathrm{~min}$ at room temperature. YFP was visualized by immunolabeling using 1:1000 chicken-anti-GFP (Aves Labs) in PBS-Tx and 1\% NDS overnight at $4^{\circ} \mathrm{C}$ followed by 1:500 donkey-anti-chicken-Alexa Fluor 488 fluorophore (Jackson ImmunoResearch Laboratories) in PBS-Tx for $2 \mathrm{~h}$ at room temperature. To facilitate anatomical characterization the sections were incubated for $30 \mathrm{~min}$ in a 1:200 Nissl-Cy5 stain (Neurotrace, Invitrogen).

Additional double-labeling immunohistochemical experiments were performed on paraformaldehyde-fixed ( $4 \%$ in $0.1 \mathrm{M} \mathrm{PB}$ ) sections from D1- and D2-GFP mice, to compare the pattern of innervation by histaminergic fibers versus the pattern of innervation provided by the dopaminergic, glutamatergic and GABAergic systems, to direct and indirect pathway MSNs in the striatum. Incubations were performed with 1:1000 chicken-anti-GFP (Aves Labs), together with 1:1000 rabbit-anti-tyrosine hydroxylase (Millipore) antibody, 1:2000 rabbit-anti-vesicular glutamate transporter type 1 (VGluT1) (Mabtech), 1:2000 rabbit-antivesicular glutamate transporter type 2 (VGluT2) (Synaptic Systems) or 1:2000 guinea pig-anti-vesicular GABA transporter (VGAT) (Synaptic Systems) antibodies. This was followed by incubation in a mixture of 1:500 donkey-anti-chicken-Alexa Fluor 488 fluorophore (Jackson ImmunoResearch) together with 1:500 donkey-anti-rabbit-Cy3 fluoro- phore (Jackson ImmunoResearch) or 1:300 donkey-anti-guinea pig-Cy5 fluorophore (Jackson ImmunoResearch) secondary antibodies.

Finally, all sections were mounted in Vectashield (Vector Laboratories) and images were captured with a LSM 710 (Zeiss) confocal microscope using ZEN and Axiovison software (Zeiss). The software's default settings for fluorophores were used for beamsplitters and ranges of emissions sampled.

Statistics. All data are presented as means \pm SEM, except where stated. Student's $t$ tests and repeated-measures ANOVA were performed using SPSS $17.0\left({ }^{*} p<0.05,{ }^{* *} p<0.01\right)$

Drugs and chemicals. All drugs were obtained from Tocris Bioscience and Sigma-Aldrich.

\section{Results}

\section{The striatum receives a sparse histaminergic innervation}

We first investigated the presence of histamine fibers in the D1 and D2 BAC transgenic mice which report the subtype of dopamine receptor by the presence of GFP. Using a polyclonal antibody against histamine we found histamine-expressing neurons only in the tuberomamillary nucleus of the hypothalamus (Fig. $1 A$ ) consistent with findings in other species (Airaksinen and Panula, 1988; Inagaki et al., 1988). We found that different areas of the brain of D1- and D2-GFP mice had different densities of histaminergic innervation. The striatum was sparsely innervated by histamine-positive fibers that often traversed the striatum in the ventrodorsal plane and possessed prominent varicosities (Fig. $1 B)$. This sparseness was especially apparent when compared with dopaminergic innervation of the striatum revealed by tyrosine hydroxylase immunostaining (Fig. 1C). The sparseness of innervation was also evident when compared with glutamatergic excitatory input from the cortex as revealed by VGluT1 immunostaining (Fig. $1 D$ ), glutamatergic excitatory input from the thalamus as revealed by VGluT2 immunostaining (Fig. $1 E$ ) and GABAergic innervation as revealed by VGAT immunostaining (Fig. $1 F$ ). Despite this sparse innervation the striatum has been reported to have a high density of histamine receptors (Hill and Young, 1980; Martinez-Mir et al., 1990; Vizuete et al., 1997; Pillot et al., 2002). Furthermore, since no specific transporter of histamine has been described (Haas and Panula, 2003), histamine, once released, could have widespread effects on striatal function. We thus determined the effect of histamine on the intrinsic properties of MSNs and both the excitatory and inhibitory inputs to MSNs.

\section{Cortical excitatory input to MSNs is negatively modulated by histamine acting at the $\mathrm{H} 3$ receptor}

First, we investigated whether the glutamatergic input from the cortex to the different classes of MSN is modulated by histamine. A stimulating electrode was placed in the external capsule and cortical afferents were activated at $10 \mathrm{~s}$ intervals while recording EPSCs in whole-cell voltage-clamp mode from direct and indirect pathway MSNs in D1- and D2-GFP mice. All the experiments were performed in the presence of the $\mathrm{GABA}_{\mathrm{A}}$ receptor antagonist SR95331 $(10 \mu \mathrm{M})$ and the $\mathrm{GABA}_{\mathrm{B}}$ receptor antagonist CGP52432 $(2 \mu \mathrm{M})$. A $5 \mathrm{~min}$ baseline response was recorded after which histamine $(10 \mu \mathrm{M})$ was washed in for $10 \mathrm{~min}$, followed by 10 min washout. The concentration of histamine was chosen in accordance with previous studies (Brown and Haas, 1999; Atzori et al., 2000; Doreulee et al., 2001) that demonstrated this to be an effective concentration to study histamine in vitro. For all electrophysiological experiments using the D1- and D2-GFP transgenic mice the MSN subtype was confirmed post hoc by immunolabeling for GFP (Fig. 2A,B). We recorded from a total 

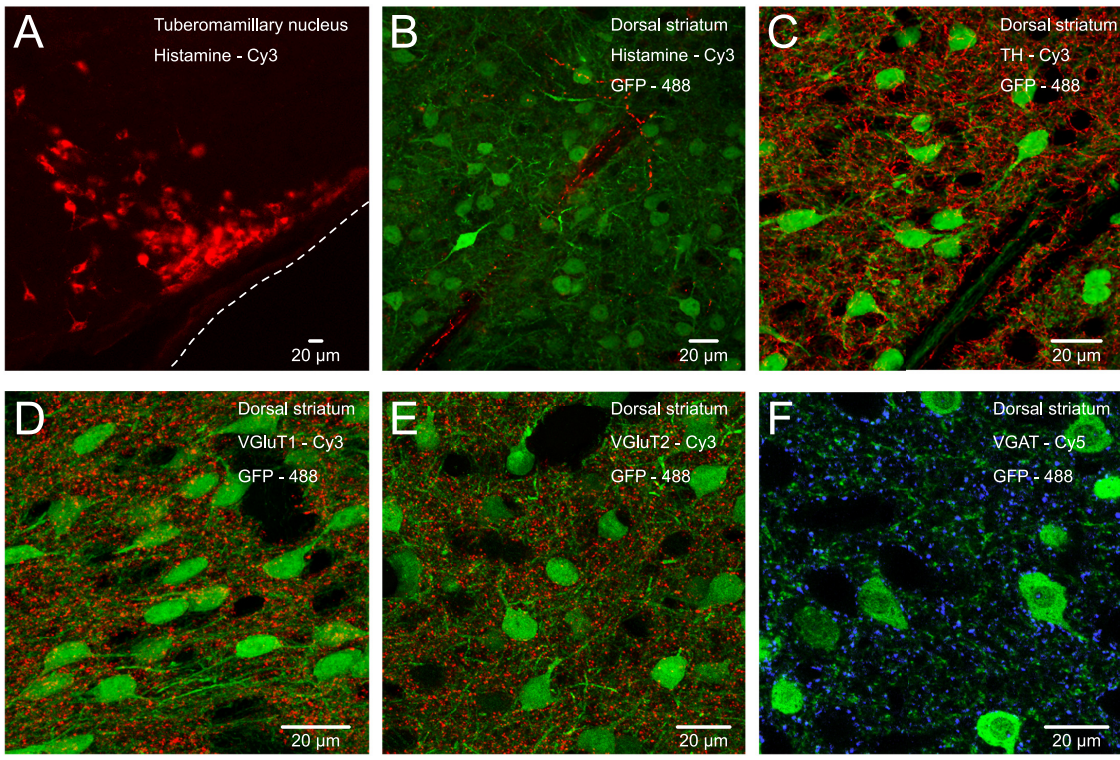

Figure 1. Histaminergic innervation of dorsal striatum. $\boldsymbol{A}$, Histamine-positive neurons in the tuberomamillary nucleus of the hypothalamus revealed using a polyclonal antibody against histamine. $\boldsymbol{B}$, Histamine-positive fibers in dorsal striatum, revealed using a polyclonal antibody against histamine (Cy3; red), among GFP-positive MSNs (Alexa Fluor 488; green) reporting the presence of $D 2$ receptors, i.e., presumed indirect pathway neurons. Note the sparse distribution and strongly varicose nature of the histamine-positive fibers. In $\boldsymbol{C}-\boldsymbol{F}$, contrast the density of histamine-positive fibers to the much higher density of dopaminergic fibers revealed by immunostaining for tyrosine hydroxylase (TH, $\mathrm{Cy3}$; red) (C), cortical terminals revealed using an antibody against vesicular glutamate transporter 1 (VGluT1, (y3; red) (D), thalamic terminals revealed using an antibody against vesicular glutamate transporter 2 (VGluT2, Cy3; red) (E), and GABAergic terminals revealed using an antibody against vesicular GABA transporter (VGAT, (y5; blue) $(\boldsymbol{F})$.

of 25 MSNs (consisting of $>80 \%$ GFP-positive neurons) in the dorsal striatum (Fig. 2Ci).

We observed a depression of cortically evoked glutamatergic transmission in response to wash-in of histamine in both D1 and D2 MSNs to $70-80 \%$ of baseline (Fig. 2Cii, D1: $81.8 \pm 6.6 \%$ and D2: $71.0 \pm 10.0 \%$; both $p<0.05$; paired samples $t$ test; $n=13$ and $n=$ 12). There was no significant difference in the histaminergicmediated depression between D1 and D2 MSNs $(p>0.05 ; n=13$ and $n=12$ ). The decrease in EPSC amplitude was blocked by coapplication of the histamine $3\left(\mathrm{H}_{3}\right)$ receptor antagonist, thioperamide $(10 \mu \mathrm{M})$ (Fig. 2Ciii, D1: $105.0 \pm 9.4 \% ; p<0.05$ and D2: $113.4 \pm$ $8.8 \% ; p<0.01$; independent samples $t$ test; $n=11$ and $n=7$ ). Washout of histamine for $10 \mathrm{~min}$ was not sufficient to reverse the depression of cortically evoked glutamatergic transmission (Fig. 2Cii), consistent with previous reports (Brown and Haas, 1999; Doreulee et al., 2001). However, we found that the negative modulation of glutamatergic transmission by histamine could be reversed by the application of thioperamide (to $102.0 \pm 9.4 \%$; $p<0.05$; paired samples $t$ test; $n=4)$. Thioperamide alone did not affect the EPSC amplitude (Fig. 2Ciii, D1: $95.8 \pm 12.8 \%$ and D2: $93.4 \pm$ $13.0 \%$; both $p>0.05$; independent samples $t$ test; $n=4$ and $n=5$ ). Last, we investigated whether lower concentrations of histamine (1 and $5 \mu \mathrm{M})$ affect corticostriatal transmission. We found that histamine at $1 \mu \mathrm{M}$ concentration already leads to a significant decrease in EPSC amplitude (to $86.7 \pm 1.6 \% ; p<0.01$; paired samples $t$ test; $n=$ $6)$, with a near maximal decrease at $5 \mu \mathrm{M}$ ( $5 \mu \mathrm{M}$ : to $62.9 \pm 5.0 \%$ and $10 \mu \mathrm{M}$ : to $59.2 \pm 6.3 \% ; p>0.05$; paired samples $t$ test) consistent with previous observations (Doreulee et al., 2001). These results suggest that histamine negatively modulates cortical excitatory inputs to both classes of MSN by acting at $\mathrm{H}_{3}$ receptors.
Thalamic excitatory input to MSNs is negatively modulated by histamine acting at the $\mathrm{H}_{3}$ receptor

We next investigated whether thalamic glutamatergic input to the different classes of MSN is modulated by histamine. To avoid antidromic activation of cortical inputs and activation of fibers of passage from other brain regions we used an optogenetic approach to isolate thalamic afferents (see Materials and Methods). In brief, the thalamic intralaminar nuclei of CaMKII-cre mice were injected with AAV2 containing the double-floxed sequence for the light activatable ion channel ChR2 and YFP (Fig. 3A). After a survival time of 3-14 weeks, brain slices were prepared as described above. The survival time enables sufficient expression of ChR2 throughout the axonal arbor of the thalamic neurons including their projection to the striatum. Fluorescence illumination of the striatum in these brain slices reveals a dense network of YFPpositive fibers (Fig. 3B,C). Whole-cell voltage-clamp recordings of striatal MSNs were performed while activating the thalamic afferents by illuminating the striatum with brief light pulses $(470 \mathrm{~nm} ; 3 \mathrm{~ms}$ duration). The subtype of MSN was confirmed post hoc by immunolabeling for preproenkephalin (PPE) which is selectively expressed by the D2 (presumed indirect pathway) MSNs (Gerfen et al., 1990) (Fig. 3B). If a recorded neuron was negative for PPE it was defined as an MSN on the basis of the somatodendritic morphology and considered a D1 (presumed direct pathway) MSN.

Recordings were made from a total of 27 neurons in the dorsal striatum, located close to YFP-expressing thalamic fibers and which all exhibited an excitatory response upon brief illumination (470 nm; $3 \mathrm{~ms}$ duration) of the striatum (Fig. 3Ci). The optically evoked EPSCs exhibited similar amplitudes, duration and short-term dynamics to those described previously using conventional electrical stimulation of thalamic afferents (Ding et al., 2008). Wash-in of histamine reduced the amplitude of the evoked thalamic EPSCs in both $\mathrm{PPE}^{-}$and $\mathrm{PPE}^{+}$neurons (Fig. $3 \mathrm{Cii} \mathrm{PPE}^{-}$: to $43.9 \pm 3.9 \%$ and $\mathrm{PPE}^{+}$: to $51.7 \pm 9.5 \%$; both $p<$ 0.01 ; paired samples $t$ test; $n=5$ and $n=7$ ). There was no significant difference in the histaminergic-mediated depression between $\mathrm{PPE}^{-}$and $\mathrm{PPE}^{+}$MSNs $(p>0.05 ; n=5$ and $n=7)$. A small number of neurons could not be classified as $\mathrm{PPE}^{-}$or $\mathrm{PPE}^{+}$following the immunolabeling, but as a group they also exhibited a similar reduction in EPSC amplitude (to $42.8 \pm 6.1 \%$; $p<0.01$; paired samples $t$ test; $n=5$ ). The decrease in EPSC amplitude was blocked by coapplication of the $\mathrm{H}_{3}$ receptor antagonist thioperamide (Fig. 3Ciii, $\mathrm{PPE}^{-}$: to $85.6 \pm 5.8 \% ; p<0.05$ and $\mathrm{PPE}^{+}$: to $110.0 \pm 8.0 \% ; p<0.01$; independent samples $t$ test; $n=4$ and $n=2)$. Thioperamide alone did not affect the EPSC amplitude (Fig. 3Ciii, $\mathrm{PPE}^{-}$: to $89.1 \pm 9.1 \%$ and $\mathrm{PPE}^{+}$: to $96.9 \pm$ 9.7\%; both $n=2$ ).

To make a direct comparison of evoked responses seen with electrical and optical stimulation, and to exclude the possibility that the observed histaminergic modulation of cortically evoked 
EPSCs could be the result of contamination by erroneous electrical activation of thalamic fibers, we repeated the cortical stimulation experiments but this time optogenetically (see Materials and Methods). Similar to electrically evoked EPSCs we observed a decrease in the amplitude of optically evoked cortical EPSCs in response to histamine (to $58.2 \pm 8.2 \%$; $p<$ 0.05 ; paired samples $t$ test; $n=7$ ). The decrease in EPSC amplitude was not significantly different from that observed using electrical stimulation $(p>0.05$; independent samples $t$ test; $n=24$ and $n=7$ ), neither were any of the measured characteristics of electrical and optical evoked EPSCs significantly different (Table 1 , all $p>0.05$; independent samples $t$ test; $n=7$ and $n=27)$. Last, the decrease in optically evoked cortical EPSC amplitude was also similar to that seen for the optically evoked thalamic EPSCs $(p>$ 0.05 ; independent samples $t$ test; $n=17$ and $n=7)$.

In conclusion, these results suggest that excitatory thalamic input to both classes of MSN, similar to that found for the excitatory cortical input, is negatively modulated by histamine acting at $\mathrm{H}_{3}$ receptors.

\section{Histamine selectively modulates the short-term dynamics of thalamostriatal synapses}

Next, we determined whether histamine is acting presynaptically or postsynaptically at the $\mathrm{H}_{3}$ receptor on cortical and thalamic afferents using a paired pulse stimulation protocol. A change in the paired pulse ratio $(\mathrm{PPR})$ would suggest histamine is acting presynaptically (Thomson, 2000). MSNs were recorded in whole-cell voltage-clamp mode while cortical or thalamic afferents were activated using a paired pulse stimulation protocol consisting of two pulses given at $50 \mathrm{~ms}$ interval.

We found that the baseline PPR of corticostriatal synapses is facilitating (Fig. 4A, D1: $1.1 \pm 0.1$ and D2: $1.1 \pm 0.1 ; n=18$ and $n=12$ ), consistent with previous observations (Ding et al., 2008). Histamine slightly increased the PPR for both classes of MSN (Fig. $4 A, D 1:$ to $1.2 \pm 0.1 ; p>0.05$ and D2: to $1.3 \pm 0.1 ; p<0.05$; paired samples $t$ test; $n=18$ and $n=12$ ) in a thioperamidesensitive manner (Fig. 4A, D1: $1.2 \pm 0.1$ and D2: $1.2 \pm 0.1 ; n=7$ and $n=5$ ). In contrast to corticostriatal synapses the baseline PPR of thalamostriatal synapses was depressing (Fig. 4C, $\mathrm{PPE}^{-}$: $0.7 \pm 0.1$ and $\mathrm{PPE}^{+}: 0.9 \pm 0.1 ; n=8$ and $\left.n=9\right)$, consistent with previous observations (Ding et al., 2008). However, the PPR increased and became significantly facilitating in the presence of histamine (Fig. $4 C, \mathrm{PPE}^{-}$: to $1.3 \pm 0.4$ and $\mathrm{PPE}+$ : to $2.0 \pm 0.6$; both $p<0.05$; independent samples $t$ test; $n=5$ and $n=6)$ in a thioperamide-sensitive manner (Fig. $4 C, \mathrm{PPE}^{-}: 0.8 \pm 0.3$ and $\operatorname{PPE}^{+}: 1.0 \pm 0.2 ; n=2$ and $\left.n=3\right)$. These results demonstrate that
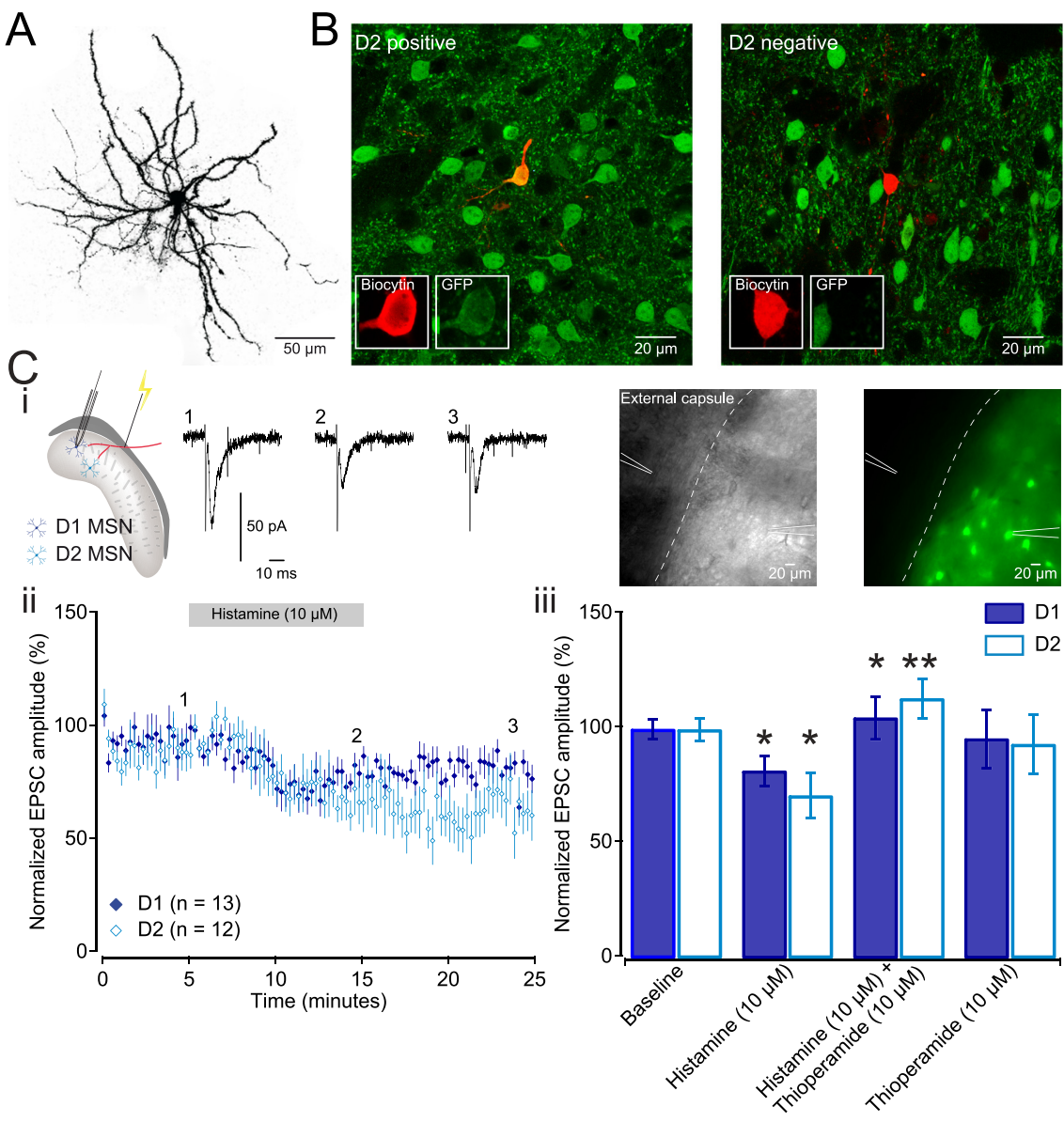

Figure 2. Cortical evoked EPSCs are negatively modulated by histamine acting at $\mathrm{H}_{3}$ receptors. $A, A Z$-stack projection of an MSN labeled with biocytin in the dorsal striatum of a D2-GFP mouse. The labeled neuron shows the typical appearance of an MSN with densely spiny dendrites. B, Post hoc immunolabeling of biocytin-labeled neurons reveals GFP-positive (left) or GFP-negative MSNs ) in a D2-GFP transgenic mouse. Insets show the labeled neurons through the red and green channels at higher magnification. (n) and fluorescence image of recording condition showing location of stimulating and recording electrodes. Cii, Plot of average, normalized EPSC amplitude (mean \pm SEM) before, during and after application of histamine. A reduction in EPSC amplitude occurred in both D1 and D2 MSNs. Ciii, Bar plot of average, normalized EPSC amplitude in the presence of histamine, in conjunction tude (baseline vs histamine; $p<0.05$ ) is blocked by coapplication of thioperamide (histamine vs histamine + thioperamide; $p<0.05$ and $p<0.01$ ), indicating that the effect is mediated through $\mathrm{H}_{3}$ receptors.

histamine tends to increase the PPR at both corticostriatal and thalamostriatal synapses suggesting that histamine acts presynaptically at $\mathrm{H}_{3}$ receptors.

To investigate the short-term dynamics at these synapses in more detail, cortical and thalamic afferents were stimulated with trains of pulses consisting of nine pulses at $20 \mathrm{~Hz}$ including a recovery pulse $500 \mathrm{~ms}$ later. Consistent with previous findings (Ding et al., 2008) corticostriatal synapses exhibited a short-term facilitation followed by a constant depressed response (Fig. $4 B$, black trace), whereas thalamostriatal synapses exhibited a constant depressed response from the first pulse onwards (Fig. $4 D$, black trace). Interestingly, we found that histamine selectively affected corticostriatal or thalamostriatal synapses. Whereas histamine did not lead to a transition in the dynamics of corticostriatal synapses (Fig. $4 B$, red trace; baseline vs histamine; $p>$ 0.05 , ANOVA, $n=6$ and $n=4$ ), the thalamostriatal synapses became significantly facilitatory throughout (Fig. $4 D$, red trace; 


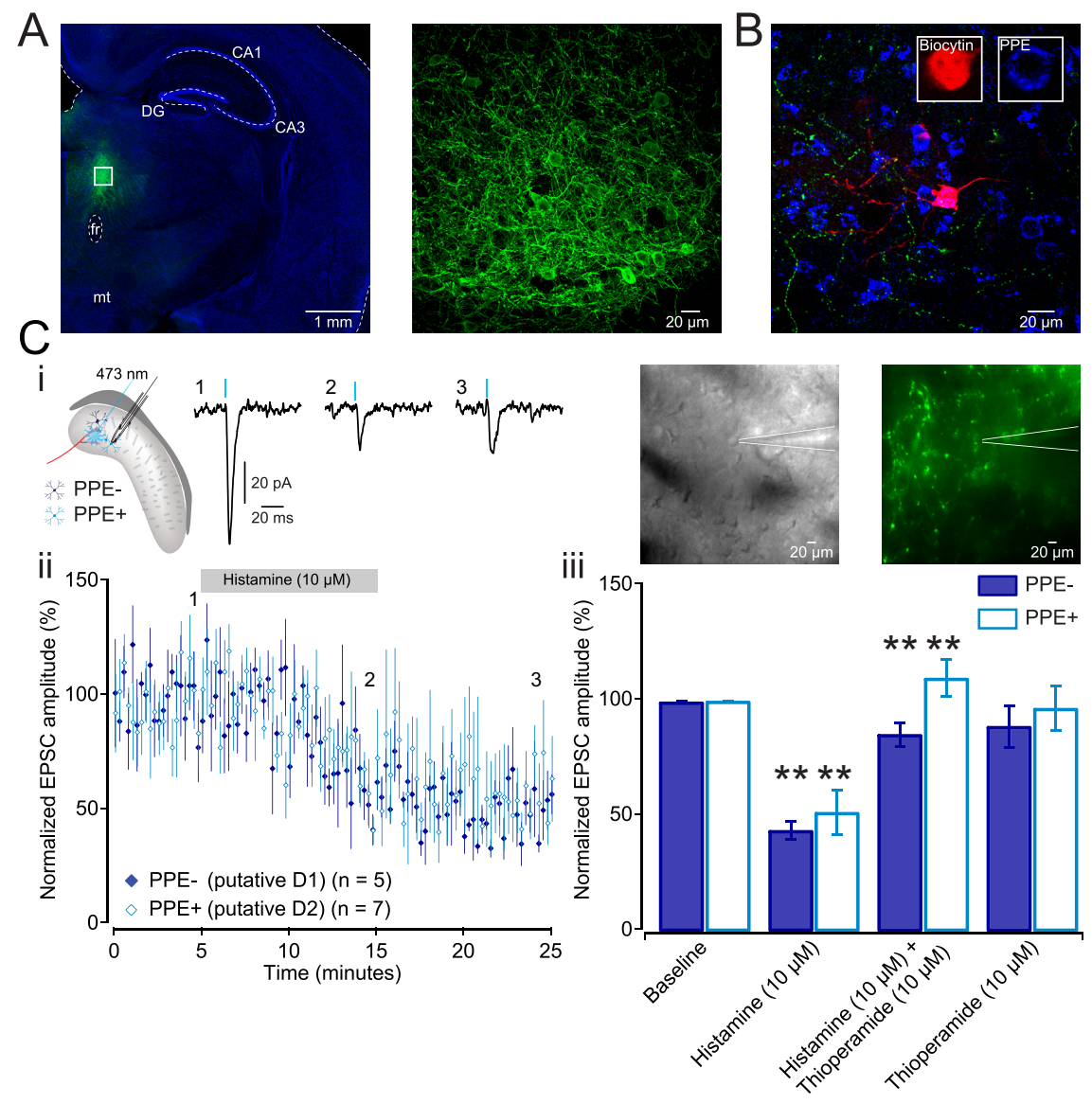

Figure 3. Thalamic evoked EPSCS are negatively modulated by histamine acting at $\mathrm{H}_{3}$ receptors. $\boldsymbol{A}$, Thalamic neurons in the intralaminar nuclei expressing both ChR2-YFP (green) following the injection of AAV (left). Section has been stained with Nissl-Cy 5 to facilitate anatomical characterization (blue). Membrane expression of ChR2-YFP in both the soma and processes of infected thalamic neurons can be seen at higher magnification (right). fr, Fasciculus retroflexus, mt, mammillothalamic tract, DG, dentate gyrus, CA1 and CA3: cornu ammonis 1 and 3 of the hippocampus. $\boldsymbol{B}$, The class of MSN was determined by immunolabeling the biocytin-labeled MSNs (red) for PPE (blue) defining the neuron as a PPE ${ }^{+}$, presumed indirect pathway MSN. Note also the YFP-expressing thalamic fibers labeled in green. $\mathrm{Ci}$, Diagram of the stimulating and recording paradigm and example single-sweep traces of EPSCs recorded from MSNs while optically stimulating the thalamic afferents before, during and after application of histamine $(10 \mu \mathrm{m})$. IRDIC and fluorescence image of recording condition showing location of recording electrode (left) and YFP-expressing thalamic fibers (right). Cii, Plot of average, normalized EPSC amplitude before, during and after application of histamine $(10 \mu \mathrm{M})$. A reduction in EPSC amplitude was observed in both PPE ${ }^{-}$and PPE ${ }^{+}$MSNs i.e., presumed direct and indirect pathway MSNs. Ciii, Bar plot of average, normalized EPSC amplitude in the presence of histamine, in conjunction with the $\mathrm{H}_{3}$ receptor antagonist, thioperamide $(10 \mu \mathrm{M})$ or thioperamide alone. The histamine-mediated reduction in EPSC amplitude (baseline vs histamine; $p<0.01$ ) is blocked by coapplication of thioperamide (histamine vs histamine + thioperamide; $p<0.01$ ) indicating that the effect is mediated through $\mathrm{H}_{3}$ receptors.

Table 1. Synaptic response properties using both electrical and optical stimulation

\begin{tabular}{lccc}
\hline & $\begin{array}{l}\text { Cortical electrical } \\
\text { stimulation }\end{array}$ & $\begin{array}{l}\text { Cortical optical } \\
\text { stimulation }\end{array}$ & $\begin{array}{l}\text { Thalamic optical } \\
\text { stimulation }\end{array}$ \\
\hline Amplitude (pA) & $88.8 \pm 15.7$ & $93.8 \pm 21.6$ & $60.5 \pm 8.7$ \\
Duration (ms) & $28.0 \pm 1.5$ & $28.7 \pm 5.7$ & $19.6 \pm 1.0$ \\
Rise time (ms) (20-80\%) & $2.2 \pm 0.2$ & $3.0 \pm 0.5$ & $3.0 \pm 0.2$ \\
Time to peak (ms) & $3.7 \pm 0.3$ & $5.0 \pm 0.8$ & $5.0 \pm 0.3$ \\
Half-decay time (ms) & $12.2 \pm 0.7$ & $11.8 \pm 2.8$ & $7.3 \pm 0.5$ \\
\hline
\end{tabular}

Data are given as mean \pm SEM.

baseline vs histamine; $p<0.01$, ANOVA; $n=17$ and $n=13)$ in a thioperamide-sensitive manner (Fig. $4 D$, gray trace; $n=2$ ).

These results suggest that histamine acts at presynaptic $\mathrm{H}_{3}$ receptors at both corticostriatal and thalamostriatal synapses. Furthermore, it suggests that histamine selectively alters the short-term dynamics of thalamostriatal synapses from depressing to facilitatory.

\section{Histamine depolarizes both classes of MSN}

The ability of cortical and thalamic excitatory inputs to initiate action potentials in a postsynaptic MSN will be dependent on the membrane voltage of the MSNs. We therefore determined whether histamine affected the resting membrane potential of MSNs using whole-cell current-clamp recordings of MSNs from D1- and D2GFP mice (Fig. 5A). The resting membrane potential of both classes of MSN was near $-80 \mathrm{mV}(\mathrm{D} 1:-79.1 \pm 2.6 \mathrm{mV}$ and D2: $-79.4 \pm 1.0 \mathrm{mV} ; n=10$ and $n=$ 11). Bath application of histamine significantly depolarized both classes of MSN (Fig. $5 B, \mathrm{D} 1$ : to $-72.7 \pm 2.6 \mathrm{mV}$ and $\mathrm{D} 2$ : to $-72.0 \pm 2.2 \mathrm{mV}$; both $p<0.01$ paired samples $t$ test; $n=10$ and $n=11$ ) and led to a decrease in input resistance (baseline: $71.6 \mathrm{M} \Omega$ and histamine: $66.5 \mathrm{M} \Omega ; p<$ 0.05; paired samples $t$ test; $n=12$ ). Next, histamine was coapplied with either the histamine $1\left(\mathrm{H}_{1}\right)$ receptor antagonist, transtriprolidine $(2 \mu \mathrm{M})$, or the histamine $2\left(\mathrm{H}_{2}\right)$ receptor antagonist, ranitidine $(5 \mu \mathrm{M})$, to investigate which histamine receptor was responsible for the observed depolarization. Coapplication with the $\mathrm{H}_{1}$ receptor antagonist did not block the histamine-mediated depolarization (Fig. 5B, D1: from $-78.0 \pm$ 2.4 to $-74.2 \pm 2.5 \mathrm{mV} ; p<0.01$ and $\mathrm{D} 2$ : from $-77.0 \pm 1.6$ to $-72.1 \pm 2.9 \mathrm{mV} ; p<$ 0.05 ; paired samples $t$ test; $n=10$ and $n=$ 11 ), whereas coapplication with the $\mathrm{H}_{2}$ receptor antagonist did significantly block the depolarization (Fig. 5B, D1: from $-82.4 \pm$ 1.1 to $-79.4 \pm 2.4 \mathrm{mV}$ and $\mathrm{D} 2$ : from $-78.7 \pm 1.2$ to $-78.2 \pm 0.4 \mathrm{mV}$; both $p>$ 0.05 ; paired samples $t$ test; $n=6$ and $n=4$ ) as well as the decrease in input resistance (baseline: $76.6 \mathrm{M} \Omega$ and histamine + ranitidine: $78.5 \mathrm{M} \Omega ; p>0.05$; paired samples $t$ test; $n=10$ ). These results suggest that histamine depolarizes both classes of MSN by acting at $\mathrm{H}_{2}$ receptors.

\section{Striatal GABAergic input to MSNs is negatively modulated by histamine}

The likelihood of a MSN to initiate an action potential is not only dependent on the excitatory drive and resting membrane potential, but also on the timing and strength of its inhibitory inputs derived from local collaterals of neighboring MSNs (Somogyi et al., 1981; Plenz, 2003; Tepper et al., 2004) and GABAergic interneurons (Kawaguchi et al., 1995; Mallet et al., 2005). We therefore determined the effect of histamine on inhibitory inputs to MSNs. The first approach was to place a stimulating electrode in the striatum at 100-200 $\mu \mathrm{m}$ from the recorded MSN to activate all striatal fibers, most likely consisting of afferents from both MSNs and interneurons. Afferents were activated at $10 \mathrm{~s}$ intervals and evoked IPSCs were recorded in whole-cell voltage-clamp as an outward current from MSNs in D1- and D2-GFP transgenic mice (Fig. 6A). All further exper- 
iments were performed in the presence of the NMDA receptor antagonist D-AP5 $(50 \mu \mathrm{M})$ and the AMPA/kainate receptor antagonist NBQX $(20 \mu \mathrm{M})$.

Bath application of histamine led to a marked reduction in IPSC amplitude in both populations of MSNs (Fig. 6B, D1: to $59.5 \pm 5.7 \%$ and $\mathrm{D} 2$ : to $40.2 \pm 1.2 \%$; $p<0.01$; paired samples $t$ test; $n=13$ and $n=8)$. There was no significant difference in the histaminergic-mediated depression between D1 and D2 MSNs ( $p>0.05 ; n=$ 13 and $n=8)$. Coapplication of the $\mathrm{H}_{3}$ receptor antagonist thioperamide completely blocked the histamine-mediated reduction in IPSC amplitude in D2 MSNs (Fig. $6 C$, to $103.7 \pm 11.4 \%$; $p<0.01$; independent samples $t$ test; $n=5$ ). However, for the population of D1 MSNs, coapplication of the $\mathrm{H}_{3}$ receptor antagonist, only partially, albeit significantly, blocked the reduction in IPSC (Fig. 6C, histamine: $59.5 \pm 5.7 \%$ vs histamine + thioperamide: $79.0 \pm 7.0 \%$; $p<0.05$ and baseline vs histamine + thioperamide: $p<0.05$; independent samples $t$ test; $n=$ 13 and $n=17)$. Thioperamide alone did not affect the IPSC amplitude (Fig. 6C, D1: to $100.7 \pm 12.7 \%$ and D2: to $103.1 \pm$ $12.0 \%$; both $p>0.05$; independent samples $t$ test; both $n=4$ ).

To further investigate how histamine modulates GABAergic inputs onto D1 MSNs we coapplied histamine with either the $\mathrm{H}_{1}$ receptor antagonist, transtriprolidine $(2 \mu \mathrm{M})$, or the $\mathrm{H}_{2}$ receptor antagonist, ranitidine $(5 \mu \mathrm{M})$. Coapplying histamine with the $\mathrm{H}_{1}$ receptor antagonist did not affect the histaminergic modulation of IPSC amplitude (Fig. 6C, to $65.0 \pm$ $8.8 \% ; p>0.05$; independent samples $t$ test; $n=13$ and $n=10$ ). However, coapplication of histamine with the $\mathrm{H}_{2}$ receptor antagonist significantly blocked part of the histaminergic modulation (Fig. $6 \mathrm{C}$, to $78.0 \pm 6.4 \% ; p<0.05$; independent samples $t$ test; $n=13$ and $n=9$ ). To conclude, these results suggest histamine strongly attenuates GABAergic transmission onto both classes of MSN by acting at $\mathrm{H}_{3}$ receptors for synapses onto D2 MSNs and at both $\mathrm{H}_{3}$ and $\mathrm{H}_{2}$ receptors for synapses onto D1 MSNs.

\section{Feedforward inhibition is not modulated by histamine}

Two major sources of GABAergic input to MSNs are the local collaterals of neighboring MSNs mediating feedback or lateral inhibition and the FSIs mediating feedforward inhibition. To investigate the contribution of each of these to the observed histaminergic modulation of GABAergic transmission we performed dual whole-cell patch-clamp recordings of connected FSI-MSN and MSN-MSN pairs.

First, we determined the effect of histamine on feedforward inhibition by performing paired recordings of connected pairs of FSIs and MSNs in Lhx6 transgenic mice, in which a subset of GABAergic interneurons express GFP (Fig. $7 A, B$ ). Both the spik-
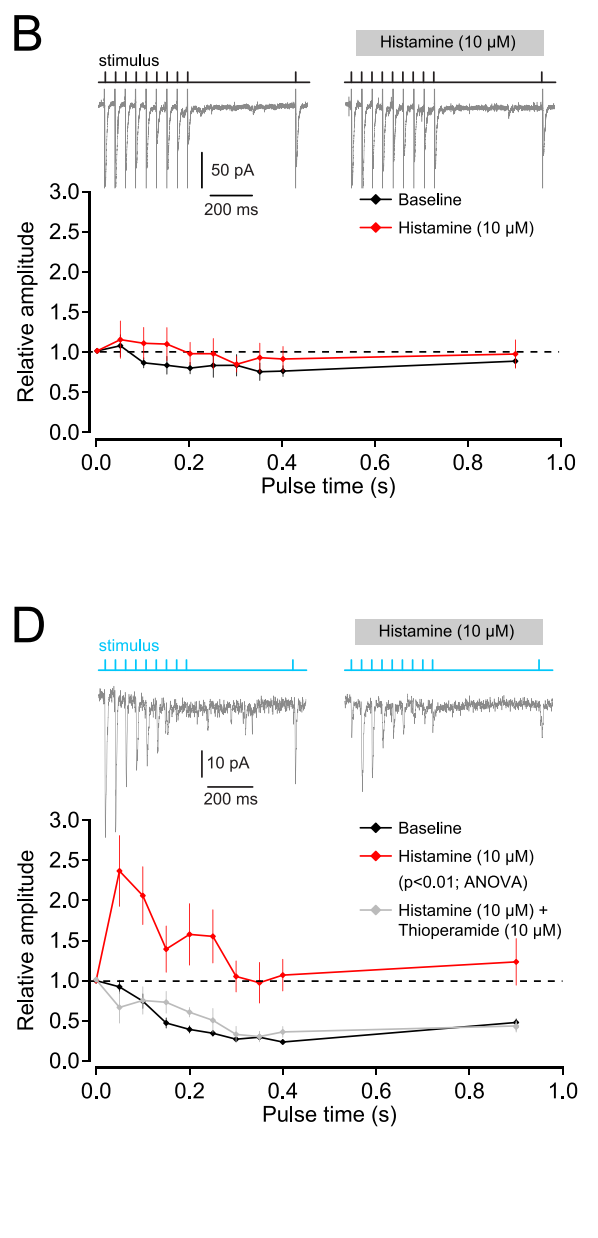

Figure 4. Short-term dynamics at corticostriatal and thalamostriatal synapses. $\boldsymbol{A}$, Diagram of the stimulating and recording paradigm and example multiple superimposed traces of EPSCS recorded from MSNs while electrically stimulating the cortical 列 thioperamide $(10 \mu \mathrm{M}) . \boldsymbol{B}$. The response to trains of stimulation of cortical afferents at $20 \mathrm{~Hz}$ is unaffected by histamine. $\boldsymbol{C}$, Diagram of the stimulating and recording paradigm and example multiple superimposed traces of EPSCs recorded from MSNs while optically stimulating the thalamic afferents before and during the application of histamine. The baseline paired pulse response is depressing at thalamostriatal synapses. However, in the presence of histamine the synaptic response becomes facilitating (baseline vs histatrains of stimulation at $20 \mathrm{~Hz}$ show that thalamic synapses become facilitatory in the presence of histamine (baseline vs histamine; $p<0.01)$. This effect is not seen with coapplication of thioperamide.

ing pattern of the recorded neurons to depolarizing current steps (Fig. 7A) and post hoc immunolabeling for parvalbumin (PV) and GFP (Fig. $7 B$ ) were used to determine FSI phenotype. Recordings were made from 10 pairs of FSIs and MSNs, of which, six were unidirectionally connected and in which a single action potential in the presynaptic FSI elicited a uIPSC in the MSN. A presynaptic action potential was elicited at $10 \mathrm{~s}$ intervals and, following a $5 \mathrm{~min}$ baseline recording, histamine was applied for $10 \mathrm{~min}$, followed by a $10 \mathrm{~min}$ washout. We found that the uIPSC amplitude was not significantly affected by the histamine application (Fig. $7 C$, to $92.7 \pm 11.7 \%$; $p>0.05$; paired samples $t$ test; $n=6$ ) and neither was the failure rate (baseline: $0.2 \pm 0.1$ and histamine: $0.3 \pm 0.1$ ).

To investigate whether the short-term dynamics at this synapse was modulated by histamine we used paired pulse and train stimulation protocols. Paired pulse stimulation consisted of two action potentials at a $50 \mathrm{~ms}$ interval elicited in the presynaptic FSI and train stimulation consisted of nine action potentials at $20 \mathrm{~Hz}$ 
A
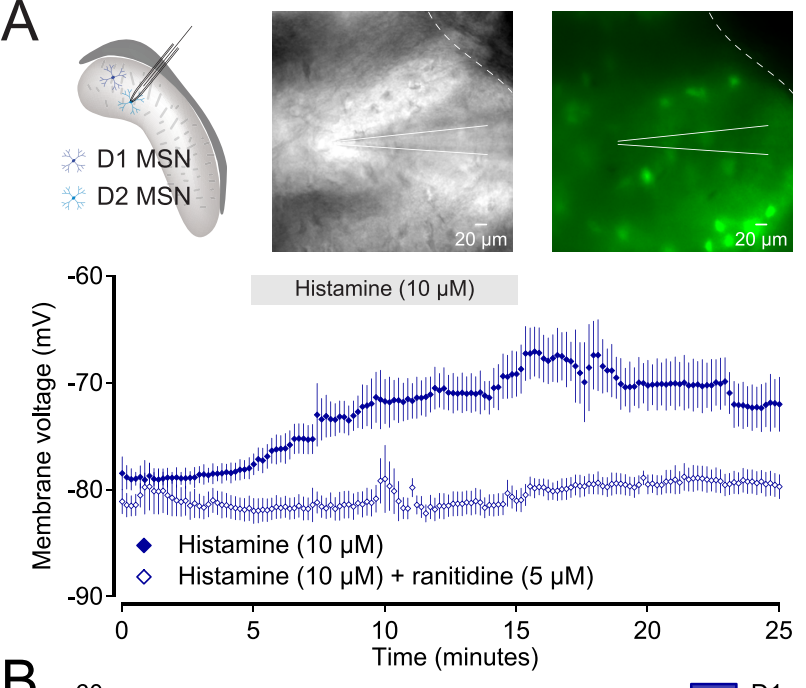

$\mathrm{B}$

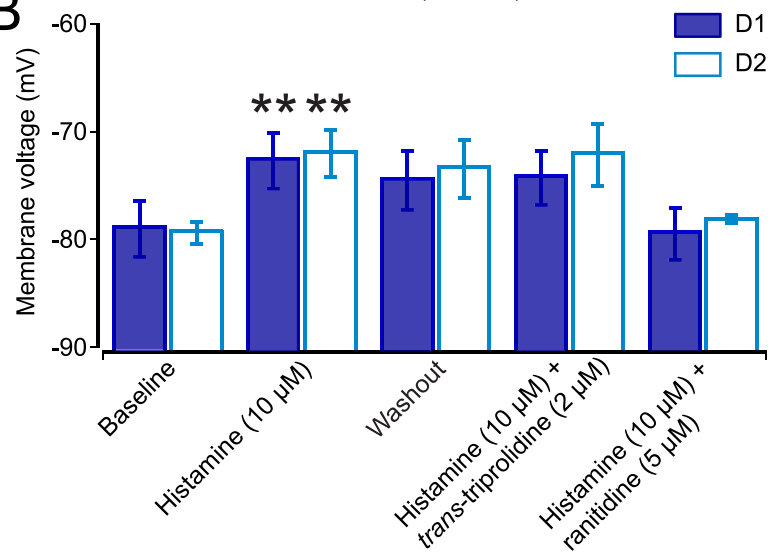

Figure 5. Depolarization of MSNs by histamine is mediated via $\mathrm{H}_{2}$ receptors. $A$, Diagram of recording paradigm and plot of average membrane voltage of MSNs before, during and after application of histamine $(10 \mu \mathrm{m})$ or histamine and the $\mathrm{H}_{2}$ receptor antagonist ranitidine $(5 \mu \mathrm{m})$. IRDIC and fluorescence image of recording condition. $\boldsymbol{B}$, Bar plot of the average membrane voltage showing a significant depolarization of both D1 and D2 MSNs in the presence of histamine (baseline vs histamine; $p<0.01$ ). This depolarization is blocked by coapplication of the $\mathrm{H}_{2}$ receptor antagonist, ranitidine (baseline vs histamine + ranitidine; $p>0.05$ ), but not the $\mathrm{H}_{1}$ receptor antagonist trans-triprolidine (baseline vs histamine + trans-triprolidine; $p<0.05$ ).

followed by a final action potential $500 \mathrm{~ms}$ later (Planert et al., 2010). Both the baseline PPR $(0.67 \pm 0.02 ; n=4)$ and the response to train stimulation throughout the $20 \mathrm{~Hz}$ train was depressing, consistent with previous reports (Gittis et al., 2010; Planert et al., 2010). Application of histamine did not affect the depressed response in the PPR $(0.6 \pm 0.2 ; p>0.05$; paired samples $t$ test; $n=4$ ) nor the depressed response to train stimulation $(p>0.05$; ANOVA; $n=5)$. Combined, these results suggest that neither the GABAergic transmission or short-term dynamics between FSIs and MSNs is modulated by histamine.

\section{Feedback inhibition between MSNs is negatively modulated by histamine}

Next, we investigated whether histamine modulates lateral inhibition between neighboring MSNs by using dual whole-cell patch-clamp recordings of connected pairs of MSNs in D1- and D2-GFP transgenic mice (Fig. 7D,E). Recordings were made from forty-four pairs of MSNs of which five were unidirectionally connected (Fig. $7 F$ ), and in which a single action potential in the presynaptic MSN elicited a uIPSC in the postsynaptic MSN. The connection probability was consistent with $\sim 10 \%$ connectivity

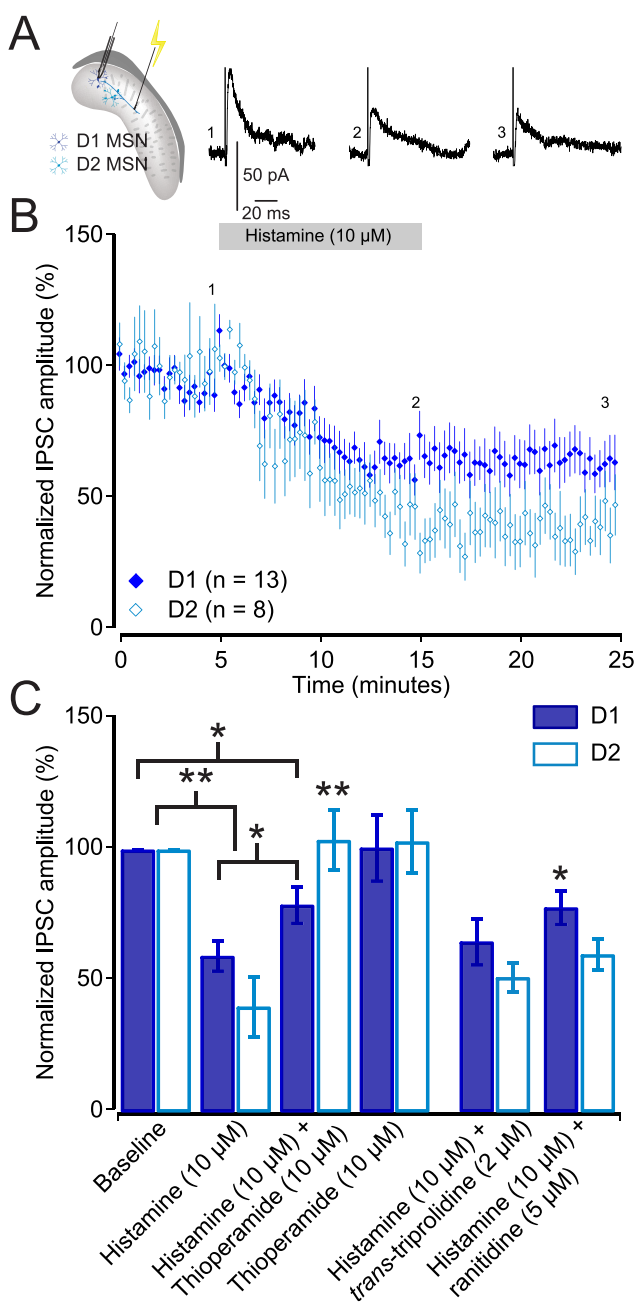

Figure 6. Striatal evoked IPSCS are negatively modulated by histamine. $\boldsymbol{A}$, Diagram of the stimulating and recording paradigm and example single-sweep traces of IPSCS recorded from MSNs while electrically stimulating striatal inhibitory afferents before, during and after application of histamine $(10 \mu \mathrm{M})$. The first positive deflection is the stimulus artifact. $\boldsymbol{B}$, Plot of average, normalized IPSC amplitude before, during and after application of histamine. A reduction in IPSC amplitude was observed for both D1 and D2 MSNs. C, Bar plot of average, normalized IPSC amplitude before, during and after application of histamine showing a significant reduction in IPSC amplitude in the presence of histamine (baseline vs histamine; $p<0.01$ ). This reduction was fully blocked when histamine was coapplied with the $\mathrm{H}_{3}$ receptor antagonist, thioperamide $(10 \mu \mathrm{m})$ for D2 MSNs (histamine vs histamine + thioperamide; $p<0.01$ ), but the reduction was only partly blocked for D1 MSNs (baseline vs histamine + thioperamide; $p<$ 0.05). Coapplication of the $\mathrm{H}_{2}$ receptor antagonist, ranitidine $(5 \mu \mathrm{m})$ also blocked part of the histamine-mediated reduction in IPSC amplitude for D1 MSNs (histamine vs histamine + ranitidine; $p<0.05)$.

as previously observed in vitro (Planert et al., 2010). A presynaptic action potential was elicited every $10 \mathrm{~s}$, and following a $5 \mathrm{~min}$ baseline recording, histamine was applied for $10 \mathrm{~min}$, which was followed by a $10 \mathrm{~min}$ washout. Histamine application abolished all uIPSCs between all the recorded pairs of MSNs (Fig. 7F, $n=$ 5). The absence of any detectable uIPSCs was not the result of an inability to elicit presynaptic action potentials. Furthermore, when the uIPSCs were blocked spontaneous PSCs could still be observed. We also studied uIPSCs evoked by multiple spikes during paired pulse and train stimulation. The baseline PPR was depressing $(0.8 \pm 0.2 ; n=5)$ and, similarly, the response to train stimulation consisted of a constant depression with a facilitated response at the test pulse, consistent with previous findings 
A

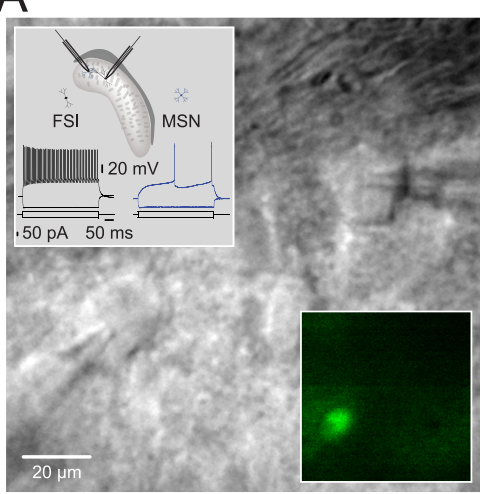

D

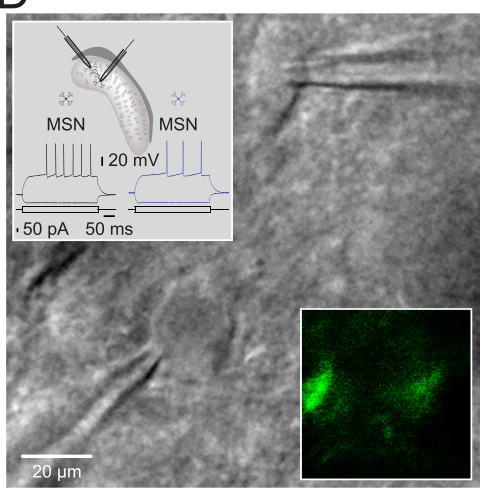

B

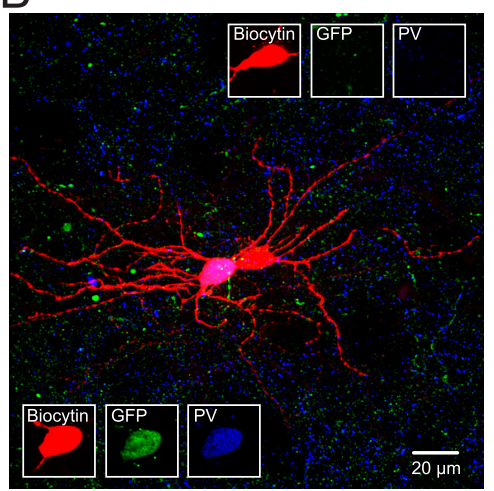

E

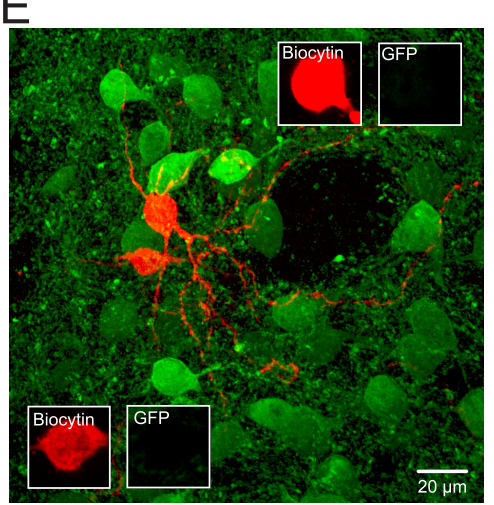

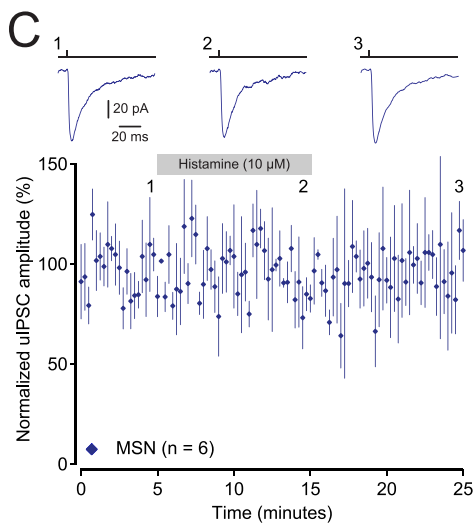

$\mathrm{F}$
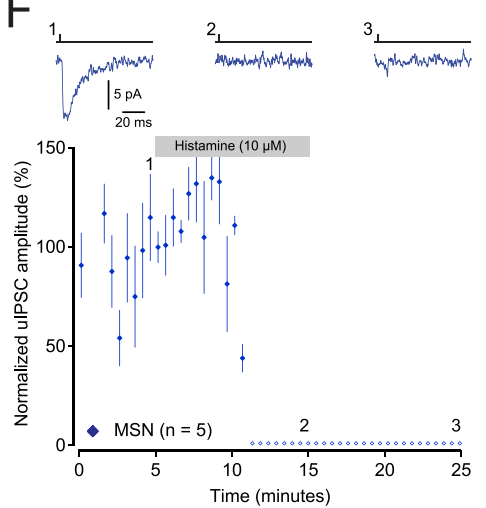

Figure 7. Inhibitory connections between neighboring MSNs, but not between FSIs and MSNs, are blocked by histamine. A, IRDIC image of the dual whole-cell patch-clamp recording configuration of a GFP-positive (left; lower inset) and GFP-negative neuron (right; lower inset) in a Lhx6-GFP transgenic mouse. Upper inset; diagram of the recording configuration consisting of dual whole-cell patch-clamp recording of a connected FSI and MSN. Example traces of spiking properties of both types of neuron in response to a suprathreshold depolarizing current step corresponding to that seen for FSIs and MSNs. B, Post hoc immunolabeling shows that the GFP-positive cell also expresses parvalbumin (PV; bottom insets) which is a marker for FSIs. The simultaneously recorded GFP-negative neuron is negative for PV (top insets) and is electrophysiologically identified as an MSN. C, Example single-sweep traces of ulPSCs as recorded from a MSN while eliciting a single action potential in the FSI before, during and after application of histamine $(10 \mu \mathrm{M})$. Note the lack of an effect of histamine on the amplitude of the response. Plot of average, normalized uIPSC amplitude before, during and after application of histamine showing that histamine did not affect the amplitude of the response. D, IRDIC image of the dual whole-cell patch-clamp recording configuration of two GFP-negative neurons (bottom inset) in a D2-GFP transgenic mouse. Top inset, Diagram of the recording configuration consisting of dual whole-cell patch-clamp recording of two connected MSNs. Example traces of spiking properties of both neurons to a suprathreshold depolarizing current step corresponding to that seen for MSNs. E, Post hoc immunolabeling for GFP confirms that both neurons are GFP-negative. $\boldsymbol{F}$, Example single-sweep traces of uIPSCS as recorded from one MSN while eliciting a single action potential in the other connected MSN before, during and after application of histamine $(10 \mu \mathrm{m})$. Note that histamine abolished the uIPSC. Plot of average normalized uIPSC amplitude before, during and after application of histamine.

(Planert et al., 2010). Interestingly, in both instances the paired pulse and train stimulation did not uncover a measurable uIPSC indicating a strong reduction of release probability by histamine. In summary, the results from the paired recording experiments suggest that histamine abolishes lateral inhibition between MSNs without affecting feedforward inhibition.

\section{Discussion}

The findings of the present study demonstrate that histamine dynamically modulates many aspects of the functional connectivity within the striatum. First, histamine suppresses both the cortical and thalamic excitatory drive to MSNs by acting at presynaptic $\mathrm{H}_{3}$ receptors. Second, histamine selectively modulates the dynamics of thalamostriatal, but not corticostriatal, synapses leading to a facilitation of the thalamic input. Thirdly, histamine abolishes lateral inhibition between MSNs without affecting feedforward inhibition mediated by FSIs onto MSNs. These findings suggest that when histaminergic neurons are active, such as during wakefulness and periods of increased attention, the striatum will have a facilitated response to thalamostriatal input and be dominated by feedforward inhibition.

\section{Sparse innervation of the striatum}

We observed a sparse innervation of the striatum by histamineimmunopositive fibers, consistent with previous findings (Takagi et al., 1986; Airaksinen and Panula, 1988). The sparse innervation, together with the fact that varicosities only infrequently make synapses (Takagi et al., 1986), raises the question of whether, and how, histamine could have widespread effects in the striatum. Although low affinity organic cation transporters might play a role in the uptake of histamine (Amphoux et al., 2006), to date no specific histamine transporter or uptake mechanism has been described in the brain. Thus, histamine is considered to be degraded in the extracellular space (Schwartz et al., 1991; Haas and Panula, 2003) with a half-life ranging in the tens of minutes (Schwartz et al., 1991). This suggests that histamine released by tonically active histaminergic neurons (Reiner and McGeer, 1987; Steininger et al., 1999; Takahashi et al., 2006) may diffuse from the site of release and affect large, if not all, areas of the striatum. The high expression of histamine receptors in the striatum (Hill and Young, 1980; Martinez-Mir et al., 1990; Vizuete et al., 1997; Pillot et al., 2002) supports the notion of a widespread effect of histamine, presumably through volume transmission. 


\section{Histaminergic modulation of excitatory inputs}

The responses of both the direct and indirect pathway MSNs to excitatory cortical and thalamic drive are controlled by neuromodulators, local interneurons, as well as reciprocal connections between MSNs. All these factors will determine if, and when, action potentials are generated by the MSNs and will determine the subsequent downstream changes in the activity of basal ganglia output nuclei, basal ganglia targets and, ultimately, behavior.

We first set out to investigate whether histamine modulates activity at the principal excitatory afferents to MSNs, i.e., those derived from the cortex and thalamus. In all our experiments we used a single concentration of histamine $(10 \mu \mathrm{M})$ which has been shown to be an effective concentration to study histamine in vitro (Brown and Haas, 1999; Atzori et al., 2000; Doreulee et al., 2001). However, it must be kept in mind that histamine concentrations in the intact brain might well be lower (Yoshitake et al., 2003; Chu et al., 2004). Deciding on the correct concentration is a general problem with in vitro preparations, as it is difficult to predict what the final concentration within the tissue will be. We therefore also studied the effect of lower concentrations of histamine ( 1 and 5 $\mu \mathrm{M})$ on cortical excitatory transmission. The baseline synaptic responses and short-term dynamics were similar to those described previously (Ding et al., 2008; but see Smeal et al., 2007) and did not differ when either electrical or optical stimulation was used. We found that histamine negatively modulates both cortical and thalamic excitatory transmission at synapses on both classes of MSNs. Coapplication of the $\mathrm{H}_{3}$ receptor antagonist thioperamide and paired pulse experiments suggest that histamine is acting presynaptically at the $\mathrm{H}_{3}$ receptor, presumably through the negative modulation of $\mathrm{Ca}^{2+}$ inflow through voltage-activated $\mathrm{Ca}^{2+}$ channels (Brown and Haas, 1999), although a postsynaptic action, especially for corticostriatal transmission, cannot be excluded. Previous autoradiographic studies had already suggested high expression levels of this receptor in both the striatum and striatal afferents (Pillot et al., 2002). The $\mathrm{H}_{3}$ receptor is one of three G-protein coupled histamine receptors described in the brain and has been suggested to modulate transmission at many synapses (Haas and Panula, 2003). Interestingly, although suggested to have a high constitutive activity (Morisset et al., 2000) we did not observe a detectable increase in the amplitude of the excitatory (or inhibitory) postsynaptic responses after application of thioperamide by itself, suggesting low constitutive activity at these synapses (Threlfell et al., 2004). Ultimately, these results imply that stronger and/or more synchronous inputs from cortex and thalamus are necessary to initiate action potentials in MSNs during periods of histaminergic activity. Such negative modulation of excitatory inputs is reminiscent of gain control used by sensory systems (Petzold et al., 2009) to keep the postsynaptic response within a normal dynamic range and preventing input saturation.

However, trains of stimulation at corticostriatal and thalamostriatal synapses revealed that histamine selectively alters the short-term dynamics of thalamostriatal synapses, changing them from depressing to facilitating synapses (Thomson, 2000). Therefore, it seems that synchronous input from the thalamus is selectively facilitated in the presence of histamine and, compared with cortical input, is more likely to lead to action potential generation in MSNs. This fits well with the suggestion for the thalamic intralaminar nuclei having a general activating function (Kinomura et al., 1996) and a histaminergic system which is important for the maintenance of arousal and vigilance (Lin et al., 1988; Parmentier et al., 2002), but it might also facilitate the transmission of sensory information to the striatum (Matsumoto et al.,
2001). Finally, the success of either cortical or thalamic excitatory input to elicit action potentials is dependent on the resting membrane potential of the MSNs. We found that MSNs are slightly depolarized by histamine acting at $\mathrm{H}_{2}$ receptors (Vizuete et al., 1997) most likely through activation of a subthreshold conductance (Haas and Panula, 2003).

\section{Histamine differentially modulates striatal inhibition}

The activity of striatal MSNs and their response to excitatory input, is further modulated by concurrent inhibition derived from collaterals of neighboring MSNs and local interneurons (Tepper and Plenz, 2006; Ponzi and Wickens, 2010). As a first test of the hypothesis that histamine modulates inhibitory input to MSNs we used intrastriatal electrical stimulation, in the presence of blockers of excitatory transmission, to recruit all inhibitory afferents to MSNs simultaneously. We observed a strong negative modulation of striatal inhibitory transmission at synapses on both classes of MSN, which was predominantly mediated through $\mathrm{H}_{3}$ receptors, although part of the modulation of the inhibitory response to D1 MSNs was through $\mathrm{H}_{2}$ receptors. This latter effect may be mediated through activation of striatal cholinergic interneurons as $\mathrm{H}_{2}$ receptor activation increases striatal acetylcholine release (Prast et al., 1999) and acetylcholine can modulate glutamatergic (Pakhotin and Bracci, 2007; Ding et al., 2010) and GABAergic transmission (Sugita et al., 1991; Koós and Tepper, 2002), although more complex interactions with other neuromodulatory pathways cannot be excluded (Threlfell and Cragg, 2011).

One might predict that the negative modulation of inhibitory currents by histamine reflects modulation of synapses located close to the soma i.e., those made by the FSIs onto MSNs (Tepper and Bolam, 2004). However, dual recordings of connected FSIMSN pairs revealed that histamine did not affect this connection. This suggests that feedforward inhibition, which has been suggested to play a role in controlling spike timing and filtering of cortical input (Koós and Tepper, 1999; Mallet et al., 2005), is not affected by the presence of histamine. The second major inhibitory input to MSNs comes from reciprocal connections between MSNs (Tepper and Plenz, 2006). These synapses are made more distally on MSN dendrites (Somogyi et al., 1981; Bolam and Izzo, 1988) and are weaker than that of FSIs (Stern et al., 1998; Wilson, 2007; Planert et al., 2010). However, as they make up 95\% of the total striatal neuron population, they could contribute substantially to the intrastriatal evoked inhibitory currents. This was confirmed by dual recordings of connected MSN-MSN pairs, which revealed that histamine abolishes the inhibitory connection between MSNs. Part of the reason why lateral inhibition is difficult to observe in vivo (Jaeger et al., 1994; Stern et al., 1998) might well be the persistent firing of histaminergic neurons under some anesthetic regimes (Reiner and McGeer, 1987). The precise role for lateral inhibition in striatal computation is still a matter of debate. It has been suggested to facilitate excitatory inputs by generating small depolarizations, mediate surround inhibition (although see Jaeger et al., 1994) or modulate dendritic processing of excitatory inputs (Carter and Sabatini, 2004; Tepper and Plenz, 2006; Wilson, 2007). Combined, these findings suggest that histamine modulates lateral inhibition between MSNs, but not feedforward inhibition mediated by FSIs, altering the response of the striatal microcircuit to excitatory inputs.

In conclusion, we suggest that histaminergic activity, during wakefulness and states of increased attention, entrains striatal information processing by differentially affecting the flow of excitatory inputs to the striatum and simultaneous intrastriatal 
processing of those inputs. Interestingly, recent studies have indicated a role for histaminergic neurotransmission in the mechanism and modulation of Tourette's syndrome (Ercan-Sencicek et al., 2010) and the effect of L-dopa treatment in Parkinson's disease (Yanovsky et al., 2011), suggesting histaminergic drugs might well be efficacious for these and other disorders involving the basal ganglia (Schwartz, 2011). Last, the widespread projections of the histaminergic system suggest that histamine might modulate information processing similarly in widespread regions of the brain.

\section{References}

Airaksinen MS, Panula P (1988) The histaminergic system in the guinea pig central nervous system: an immunocytochemical mapping study using an antiserum against histamine. J Comp Neurol 273:163-186.

Amphoux A, Vialou V, Drescher E, Brüss M, Mannoury La Cour C, Rochat C, Millan MJ, Giros B, Bönisch H, Gautron S (2006) Differential pharmacological in vitro properties of organic cation transporters and regional distribution in rat brain. Neuropharmacology 50:941-952.

Anaclet C, Parmentier R, Ouk K, Guidon G, Buda C, Sastre JP, Akaoka H, Sergeeva OA, Yanagisawa M, Ohtsu H, Franco P, Haas HL, Lin JS (2009) Orexin/hypocretin and histamine: distinct roles in the control of wakefulness demonstrated using knock-out mouse models. J Neurosci 29:14423-14438.

Aston-Jones G, Bloom FE (1981) Activity of norepinephrine-containing locus coeruleus neurons in behaving rats anticipates fluctuations in the sleep-waking cycle. J Neurosci 1:876-886.

Atzori M, Lau D, Tansey EP, Chow A, Ozaita A, Rudy B, McBain CJ (2000) $\mathrm{H} 2$ histamine receptor-phosphorylation of Kv3.2 modulates interneuron fast spiking. Nat Neurosci 3:791-798.

Bolam JP, Izzo PN (1988) The postsynaptic targets of substance P-immunoreactive terminals in the rat neostriatum with particular reference to identified spiny striatonigral neurons. Exp Brain Res 70:361-377.

Brown RE, Haas HL (1999) On the mechanism of histaminergic inhibition of glutamate release in the rat dentate gyrus. J Physiol 515:777-786.

Carter AG, Sabatini BL (2004) State-dependent calcium signaling in dendritic spines of striatal medium spiny neurons. Neuron 44:483-493.

Chu M, Huang ZL, Qu WM, Eguchi N, Yao MH, Urade Y (2004) Extracellular histamine level in the frontal cortex is positively correlated with the amount of wakefulness in rats. Neurosci Res 49:417-420.

Ding J, Peterson JD, Surmeier DJ (2008) Corticostriatal and thalamostriatal synapses have distinctive properties. J Neurosci 28:6483-6492.

Ding JB, Guzman JN, Peterson JD, Goldberg JA, Surmeier DJ (2010) Thalamic gating of corticostriatal signaling by cholinergic interneurons. Neuron 67:294-307.

Doig NM, Moss J, Bolam JP (2010) Cortical and thalamic innervation of direct and indirect pathway medium-sized spiny neurons in mouse striatum. J Neurosci 30:14610-14618.

Doreulee N, Yanovsky Y, Flagmeyer I, Stevens DR, Haas HL, Brown RE (2001) Histamine $H(3)$ receptors depress synaptic transmission in the corticostriatal pathway. Neuropharmacology 40:106-113.

Ercan-Sencicek AG, Stillman AA, Ghosh AK, Bilguvar K, O'Roak BJ, Mason CE, Abbott T, Gupta A, King RA, Pauls DL, Tischfield JA, Heiman GA, Singer HS, Gilbert DL, Hoekstra PJ, Morgan TM, Loring E, Yasuno K, Fernandez T, Sanders S, et al (2010) L-histidine decarboxylase and Tourette's syndrome. N Engl J Med 362:1901-1908.

Gerfen CR, Engber TM, Mahan LC, Susel Z, Chase TN, Monsma FJ Jr, Sibley DR (1990) D1 and D2 dopamine receptor-regulated gene expression of striatonigral and striatopallidal neurons. Science 250:1429-1432.

Gittis AH, Nelson AB, Thwin MT, Palop JJ, Kreitzer AC (2010) Distinct roles of GABAergic interneurons in the regulation of striatal output pathways. J Neurosci 30:2223-2234.

Gong S, Zheng C, Doughty ML, Losos K, Didkovsky N, Schambra UB, Nowak NJ, Joyner A, Leblanc G, Hatten ME, Heintz N (2003) A gene expression atlas of the central nervous system based on bacterial artificial chromosomes. Nature 425:917-925.

Graybiel AM, Aosaki T, Flaherty AW, Kimura M (1994) The basal ganglia and adaptive motor control. Science 265:1826-1831.

Grillner S, Hellgren J, Ménard A, Saitoh K, Wikström MA (2005) Mechanisms for selection of basic motor programs-roles for the striatum and pallidum. Trends Neurosci 28:364-370.
Haas H, Panula P (2003) The role of histamine and the tuberomamillary nucleus in the nervous system. Nat Rev Neurosci 4:121-130.

Hill SJ, Young JM (1980) Histamine H1-receptors in the brain of the guinea-pig and the rat: differences in ligand binding properties and regional distribution. Br J Pharmacol 68:687-696.

Inagaki $\mathrm{N}$, Yamatodani $\mathrm{A}$, Ando-Yamamoto $\mathrm{M}$, Tohyama $\mathrm{M}$, Watanabe $\mathrm{T}$, Wada H (1988) Organization of histaminergic fibers in the rat brain. J Comp Neurol 273:283-300.

Jaeger D, Kita H, Wilson CJ (1994) Surround inhibition among projection neurons is weak or nonexistent in the rat neostriatum. J Neurophysiol 72:2555-2558.

Kawaguchi Y, Wilson CJ, Augood SJ, Emson PC (1995) Striatal interneurones: chemical, physiological and morphological characterization. Trends Neurosci 18:527-535.

Kincaid AE, Zheng T, Wilson CJ (1998) Connectivity and convergence of single corticostriatal axons. J Neurosci 18:4722-4731.

Kinomura S, Larsson J, Gulyás B, Roland PE (1996) Activation by attention of the human reticular formation and thalamic intralaminar nuclei. Science 271:512-515.

Koós T, Tepper JM (1999) Inhibitory control of neostriatal projection neurons by GABAergic interneurons. Nat Neurosci 2:467-472.

Koós T, Tepper JM (2002) Dual cholinergic control of fast-spiking interneurons in the neostriatum. J Neurosci 22:529-535.

Kravitz AV, Freeze BS, Parker PR, Kay K, Thwin MT, Deisseroth K, Kreitzer AC (2010) Regulation of parkinsonian motor behaviours by optogenetic control of basal ganglia circuitry. Nature 466:622-626.

Kuramoto E, Furuta T, Nakamura KC, Unzai T, Hioki H, Kaneko T (2009) Two types of thalamocortical projections from the motor thalamic nuclei of the rat: a single neuron-tracing study using viral vectors. Cereb Cortex 19:2065-2077.

Lacey CJ, Bolam JP, Magill PJ (2007) Novel and distinct operational principles of intralaminar thalamic neurons and their striatal projections. J Neurosci 27:4374-4384.

Lin JS, Sakai K, Jouvet M (1988) Evidence for histaminergic arousal mechanisms in the hypothalamus of cat. Neuropharmacology 27:111-122.

Mallet N, Le Moine C, Charpier S, Gonon F (2005) Feedforward inhibition of projection neurons by fast-spiking GABA interneurons in the rat striatum in vivo. J Neurosci 25:3857-3869.

Martinez-Mir MI, Pollard H, Moreau J, Arrang JM, Ruat M, Traiffort E, Schwartz JC, Palacios JM (1990) Three histamine receptors (H1, H2 and H3) visualized in the brain of human and non-human primates. Brain Res 526:322-327.

Mathur BN, Capik NA, Alvarez VA, Lovinger DM (2011) Serotonin induces long-term depression at corticostriatal synapses. J Neurosci 31:7402-7411.

Matsumoto N, Minamimoto T, Graybiel AM, Kimura M (2001) Neurons in the thalamic CM-Pf complex supply striatal neurons with information about behaviorally significant sensory events. J Neurophysiol 85:960-976.

Morisset S, Rouleau A, Ligneau X, Gbahou F, Tardivel-Lacombe J, Stark H, Schunack W, Ganellin CR, Schwartz JC, Arrang JM (2000) High constitutive activity of native $\mathrm{H} 3$ receptors regulates histamine neurons in brain. Nature 408:860-864.

Munakata M, Akaike N (1994) Regulation of $\mathrm{K}^{+}$conductance by histamine $\mathrm{H} 1$ and $\mathrm{H} 2$ receptors in neurones dissociated from rat neostriatum. J Physiol 480:233-245.

Pakhotin P, Bracci E (2007) Cholinergic interneurons control the excitatory input to the striatum. J Neurosci 27:391-400.

Parent M, Wallman MJ, Gagnon D, Parent A (2011) Serotonin innervation of basal ganglia in monkeys and humans. J Chem Neuroanat 41:256-265.

Parmentier R, Ohtsu H, Djebbara-Hannas Z, Valatx JL, Watanabe T, Lin JS (2002) Anatomical, physiological, and pharmacological characteristics of histidine decarboxylase knock-out mice: evidence for the role of brain histamine in behavioral and sleep-wake control. J Neurosci 22:7695-7711.

Petzold GC, Hagiwara A, Murthy VN (2009) Serotonergic modulation of odor input to the mammalian olfactory bulb. Nat Neurosci 12:784-791.

Pillot C, Heron A, Cochois V, Tardivel-Lacombe J, Ligneau X, Schwartz JC, Arrang JM (2002) A detailed mapping of the histamine H(3) receptor and its gene transcripts in rat brain. Neuroscience 114:173-193.

Planert H, Szydlowski SN, Hjorth JJ, Grillner S, Silberberg G (2010) Dynamics of synaptic transmission between fast-spiking interneurons and 
striatal projection neurons of the direct and indirect pathways. J Neurosci 30:3499-3507.

Plenz D (2003) When inhibition goes incognito: feedback interaction between spiny projection neurons in striatal function. Trends Neurosci 26:436-443.

Ponzi A, Wickens J (2010) Sequentially switching cell assemblies in random inhibitory networks of spiking neurons in the striatum. J Neurosci 30:5894-5911.

Prast H, Tran MH, Lamberti C, Fischer H, Kraus M, Grass K, Philippu A (1999) Histaminergic neurons modulate acetylcholine release in the ventral striatum: role of $\mathrm{H} 1$ and $\mathrm{H} 2$ histamine receptors. Naunyn Schmiedebergs Arch Pharmacol 360:552-557.

Reiner PB, McGeer EG (1987) Electrophysiological properties of cortically projecting histamine neurons of the rat hypothalamus. Neurosci Lett 73:43-47.

Schultz W (2002) Getting formal with dopamine and reward. Neuron $36: 241-263$

Schwartz JC (2011) The histamine H3 receptor: from discovery to clinical trials with pitolisant. Br J Pharmacol 163:713-721.

Schwartz JC, Arrang JM, Garbarg M, Pollard H, Ruat M (1991) Histaminergic transmission in the mammalian brain. Physiol Rev 71:1-51.

Smeal RM, Gaspar RC, Keefe KA, Wilcox KS (2007) A rat brain slice preparation for characterizing both thalamostriatal and corticostriatal afferents. J Neurosci Methods 159:224-235.

Smith Y, Bevan MD, Shink E, Bolam JP (1998) Microcircuitry of the direct and indirect pathways of the basal ganglia. Neuroscience 86:353-387.

Somogyi P, Bolam JP, Smith AD (1981) Monosynaptic cortical input and local axon collaterals of identified striatonigral neurons. A light and electron microscopic study using the Golgi-peroxidase transport-degeneration procedure. J Comp Neurol 195:567-584.

Steinbusch HW (1981) Distribution of serotonin-immunoreactivity in the central nervous system of the rat-cell bodies and terminals. Neuroscience 6:557-618.

Steininger TL, Alam MN, Gong H, Szymusiak R, McGinty D (1999) Sleepwaking discharge of neurons in the posterior lateral hypothalamus of the albino rat. Brain Res 840:138-147.

Stern EA, Jaeger D, Wilson CJ (1998) Membrane potential synchrony of simultaneously recorded striatal spiny neurons in vivo. Nature 394:475-478

Sugita S, Uchimura N, Jiang ZG, North RA (1991) Distinct muscarinic receptors inhibit release of gamma-aminobutyric acid and excitatory amino acids in mammalian brain. Proc Natl Acad Sci U S A 88:2608-2611.
Surmeier DJ, Ding J, Day M, Wang Z, Shen W (2007) D1 and D2 dopaminereceptor modulation of striatal glutamatergic signaling in striatal medium spiny neurons. Trends Neurosci 30:228-235.

Takagi H, Morishima Y, Matsuyama T, Hayashi H, Watanabe T, Wada $\mathrm{H}$ (1986) Histaminergic axons in the neostriatum and cerebral cortex of the rat: a correlated light and electron microscopic immunocytochemical study using histidine decarboxylase as a marker. Brain Res 364:114-123.

Takahashi K, Lin JS, Sakai K (2006) Neuronal activity of histaminergic tuberomammillary neurons during wake-sleep states in the mouse. J Neurosci 26:10292-10298.

Tepper JM, Bolam JP (2004) Functional diversity and specificity of neostriatal interneurons. Curr Opin Neurobiol 14:685-692.

Tepper JM, Plenz D (2006) Microcircuits in the striatum: striatal cell types and their interaction. In: Microcircuits: the interface between neurons and global brain function (Grillner S, Graybiel AM, eds), pp 127-148. Cambridge, MA: MIT.

Tepper JM, Koós T, Wilson CJ (2004) GABAergic microcircuits in the neostriatum. Trends Neurosci 27:662-669.

Thomson AM (2000) Molecular frequency filters at central synapses. Prog Neurobiol 62:159-196.

Threlfell S, Cragg SJ (2011) Dopamine signaling in dorsal versus ventral striatum: the dynamic role of cholinergic interneurons. Front Syst Neurosci 5:11.

Threlfell S, Cragg SJ, Kalló I, Turi GF, Coen CW, Greenfield SA (2004) Histamine $\mathrm{H} 3$ receptors inhibit serotonin release in substantia nigra pars reticulata. J Neurosci 24:8704-8710.

Ungless MA (2004) Dopamine: the salient issue. Trends Neurosci 27:702-706.

Vizuete ML, Traiffort E, Bouthenet ML, Ruat M, Souil E, Tardivel-Lacombe J, Schwartz JC (1997) Detailed mapping of the histamine $\mathrm{H} 2$ receptor and its gene transcripts in guinea-pig brain. Neuroscience 80:321-343.

Wilson CJ (2007) GABAergic inhibition in the neostriatum. Prog Brain Res 160:91-110.

Yanovsky Y, Li S, Klyuch BP, Yao Q, Blandina P, Passani MB, Lin JS, Haas H, Sergeeva OA (2011) L-Dopa activates histaminergic neurons. J Physiol 589:1349-1366

Yin HH, Knowlton BJ (2006) The role of the basal ganglia in habit formation. Nat Rev Neurosci 7:464-476.

Yoshitake T, Yamaguchi M, Nohta H, Ichinose F, Yoshida H, Yoshitake S, Fuxe K, Kehr J (2003) Determination of histamine in microdialysis samples from rat brain by microbore column liquid chromatography following intramolecular excimer-forming derivatization with pyrene-labeling reagent. J Neurosci Methods 127:11-17. 